\title{
Therapeutic Strategies to Target Calcium Dysregulation in Alzheimer's Disease
}

\author{
Maria Calvo-Rodriguez ${ }^{\circledR}$, Elizabeth K. Kharitonova and Brian J. Bacskai * \\ Alzheimer Research Unit, Department of Neurology, Massachusetts General Hospital and Harvard Medical \\ School, Charlestown, MA 02129, USA; mcalvorodriguez@mgh.harvard.edu (M.C.-R.); \\ ekharitonova@mgh.harvard.edu (E.K.K.) \\ * Correspondence: bbacskai@mgh.harvard.edu; Tel.: +1-617-724-5306
}

Received: 27 October 2020; Accepted: 18 November 2020; Published: 20 November 2020

\begin{abstract}
Alzheimer's disease (AD) is the most common form of dementia, affecting millions of people worldwide. Unfortunately, none of the current treatments are effective at improving cognitive function in $\mathrm{AD}$ patients and, therefore, there is an urgent need for the development of new therapies that target the early cause(s) of $\mathrm{AD}$. Intracellular calcium $\left(\mathrm{Ca}^{2+}\right)$ regulation is critical for proper cellular and neuronal function. It has been suggested that $\mathrm{Ca}^{2+}$ dyshomeostasis is an upstream factor of many neurodegenerative diseases, including AD. For this reason, chemical agents or small molecules aimed at targeting or correcting this $\mathrm{Ca}^{2+}$ dysregulation might serve as therapeutic strategies to prevent the development of $\mathrm{AD}$. Moreover, neurons are not alone in exhibiting $\mathrm{Ca}^{2+}$ dyshomeostasis, since $\mathrm{Ca}^{2+}$ disruption is observed in other cell types in the brain in AD. In this review, we examine the distinct $\mathrm{Ca}^{2+}$ channels and compartments involved in the disease mechanisms that could be potential targets in $\mathrm{AD}$.
\end{abstract}

Keywords: calcium homeostasis; Alzheimer's disease; therapeutics; amyloid; tau; endoplasmic reticulum; mitochondria; lysosomes

\section{Calcium Dysregulation Is a Hallmark of Alzheimer's Disease}

Alzheimer's disease (AD) is the most common form of dementia, affecting more than 30 million people worldwide. It is characterized by accumulation of extracellular amyloid $\beta(A \beta)$ plaques—or senile plaques-composed of $A \beta$ peptide, intraneuronal fibrillary tangles (NFTs) comprising hyperphosphorylated and misfolded microtubule-associated protein tau, and selective neuronal loss, particularly in brain regions like the neocortex and hippocampus, eventually leading to memory loss and a decline in cognitive function. Most AD cases are sporadic (SAD), with less than $1 \%$ due to genetic mutations. Risk factors, such as aging, lifestyle, obesity, or diabetes, or genetic factors such as carrying the allele $\varepsilon 4$ in the apolipoprotein $\mathrm{E}$ (ApoE) gene predispose individuals to SAD development [1]. Genetically inherited forms of AD (familial AD, FAD) show early onset and are caused by mutations in genes coding for presenilin (PS) 1, PS2, or amyloid precursor protein (APP), all involved in the $\mathrm{A} \beta$ generation pathway. Other than the onset, there are no clear differences regarding symptoms or histopathological features between SAD and FAD. Different hypotheses have been proposed to explain the origin of AD. The relation to genetics in FAD supported the "amyloid cascade hypothesis", which suggests that $\mathrm{AD}$ pathogenesis is initiated by overproduction of $\mathrm{A} \beta$ and/or failure of its clearance mechanisms, upstream of tau dysregulation [2]. However, other hypotheses that explain the etiology of AD are being considered. The "cholinergic hypothesis" [3], "tau propagation hypothesis" [4], "inflammatory hypothesis" [5], or "glymphatic system hypothesis" [6] are among the most relevant. 
Intracellular calcium $\left(\mathrm{Ca}^{2+}\right)$ is an important second messenger that regulates multiple cellular functions, such as synaptic plasticity, action potentials, and learning and memory. $\mathrm{Ca}^{2+}$ dyshomeostasis, on the other hand, contributes to detrimental mechanisms such as necrosis, apoptosis, autophagy deficits, and neurodegeneration. Perturbations in intracellular $\mathrm{Ca}^{2+}$ are involved in many neurodegenerative diseases including AD, Parkinson's disease, and Huntington's disease [7]. Back in the mid-1980s, Khachaturian proposed that $\mathrm{Ca}^{2+}$ dysregulation led to neurodegeneration, suggesting that a sustained imbalance of cellular $\mathrm{Ca}^{2+}$ could disrupt normal neuronal functions and lead to neurodegenerative diseases such as AD [8]. Since then, many reports have shown $\mathrm{Ca}^{2+}$ dysregulation in $\mathrm{AD}$ (both in SAD [9,10] and in FAD [11]), animal models of the disorder [12-19], and cells from human AD patients [20]. The " $\mathrm{Ca}^{2+}$ hypothesis of Alzheimer's disease" [21] postulates that activation of the amyloidogenic pathway causes a remodeling of normal neuronal $\mathrm{Ca}^{2+}$ signaling pathways, which then alters $\mathrm{Ca}^{2+}$ homeostasis and leads to the disruption of the mechanisms involved in learning and memory. Neuronal $\mathrm{Ca}^{2+}$ dyshomeostasis seems to manifest early in $\mathrm{AD}$ progression prior to the development of histopathological markers or clinical symptoms [22]. Similarly, AD is also marked by $\mathrm{Ca}^{2+}$ disruption in other cells in the brain such as astrocytes and microglia. Whether disruption of $\mathrm{Ca}^{2+}$ homeostasis is cause or consequence of AD pathology is still a matter of debate.

Up to date, there are only two types of Food and Drug Administration (FDA)-approved therapies for AD treatment (www.alzforum.org) - acetylcholinesterase inhibitors and N-methyl-D-aspartate receptor (NMDAR) antagonists—and neither can cure or reverse the disease, but can, at least, transiently relieve patients' symptoms [23]. Unfortunately, drugs targeting A $\beta$ have been mostly unsuccessful. Although these therapies have shown some success in clearing A $\beta$ plaques from the AD brain, they have failed to relieve the cognitive decline of $\mathrm{AD}$ patients in clinical trials [24], with the exception of aducanumab, which demonstrated both clearance of plaques and modest gains in cognitive function [25]. In addition, the well-known lack of correlation between cognitive symptoms and A $\beta$ deposition further supports the idea of the need for different approaches [26]. $\mathrm{Ca}^{2+}$ dyshomeostasis is an early molecular defect in AD and might precede $A \beta$ and tau deposition [22]. Therefore, therapeutics that stabilize $\mathrm{Ca}^{2+}$ signals may represent an alternative strategy for treating $\mathrm{AD}$. In the remaining sections, we review human data and those generated from experimental models, and we discuss the different strategies for targeting $\mathrm{Ca}^{2+}$ dysregulation-including specific $\mathrm{Ca}^{2+}$ channels and different cell types-that could be used as therapeutics in AD.

\section{Neuronal $\mathrm{Ca}^{2+}$ as a Therapeutic Target in $\mathrm{AD}$}

$\mathrm{Ca}^{2+}$ is a fundamental regulator of neuronal fate; thus, intracellular $\mathrm{Ca}^{2+}$ homeostasis must be finely tuned in physiological conditions. In the extracellular space, $\mathrm{Ca}^{2+}$ concentration is maintained between 1.1 and $1.4 \mathrm{mM}$, whereas resting cytosolic levels within neurons are maintained in the $\mathrm{nM}$ range (50-300 $\mathrm{nM}$ ) [27]. After cell activation, intracellular $\mathrm{Ca}^{2+}$ concentrations increase rapidly to the $\mu \mathrm{M}$ range. This $\mathrm{Ca}^{2+}$ gradient allows the initiation of different signaling cascades. $\mathrm{Ca}^{2+}$ levels in the endoplasmic reticulum (ER) are nearly a thousand times higher than those of the cytoplasm [28]. $\mathrm{Ca}^{2+}$ signals are generated by the influx of $\mathrm{Ca}^{2+}$ from the extracellular space or by $\mathrm{Ca}^{2+}$ release from intracellular stores. $\mathrm{Ca}^{2+}$ enters neurons mainly through plasma membrane channels and is then buffered by $\mathrm{Ca}^{2+}$-binding proteins and organelles such as mitochondria. Even though the mechanisms responsible for neuronal $\mathrm{Ca}^{2+}$ dysregulation in $\mathrm{AD}$ are not completely understood, as discussed in the sections below, evidence shows that different compartments and/or organelles are involved (Figure 1). 


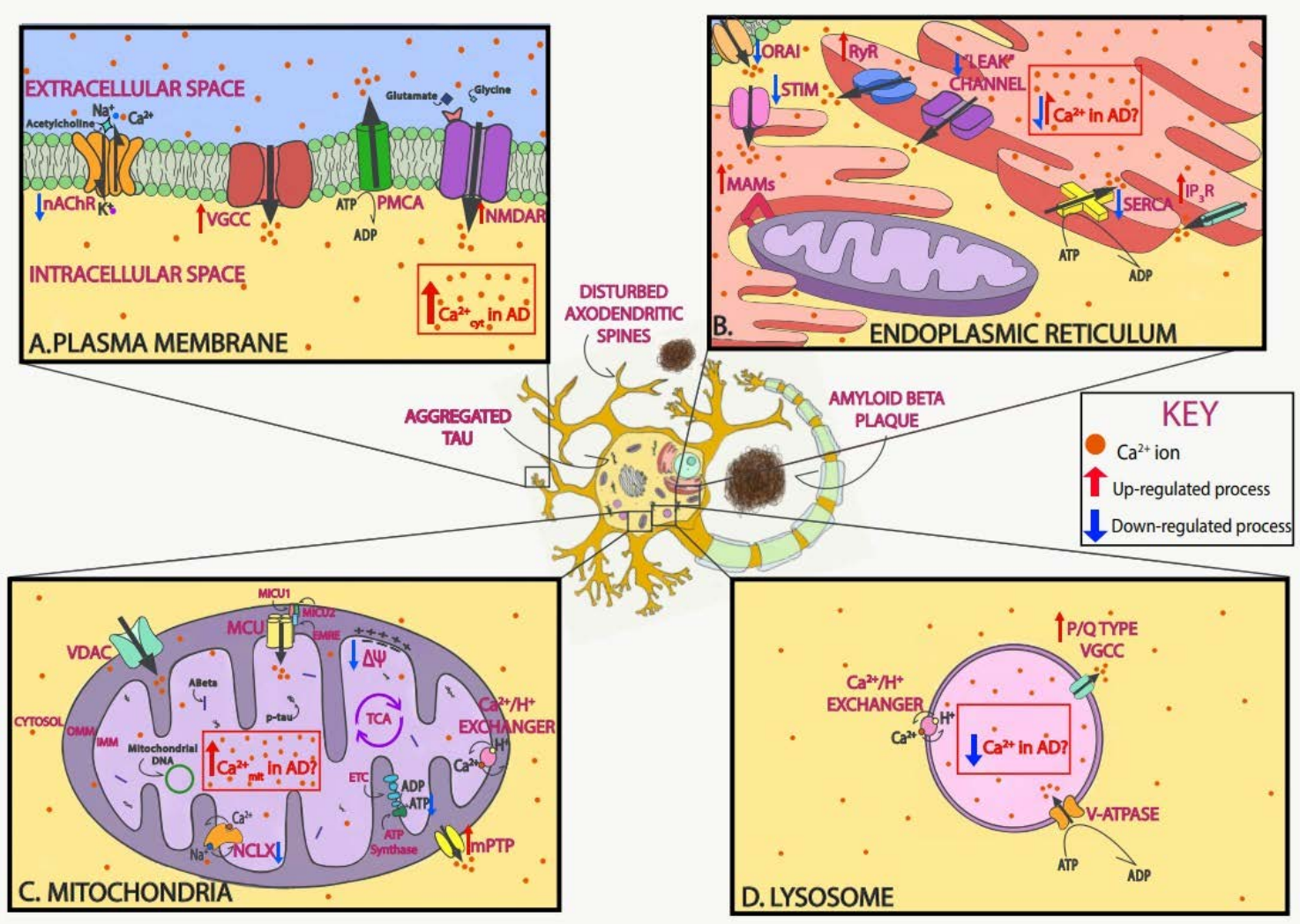

Figure 1. Neuronal $\mathrm{Ca}^{2+}$ as a therapeutic target in Alzheimer's disease (AD). Schematic of $\mathrm{Ca}^{2+}$ dysregulation in neurons in $\mathrm{AD}$ that could be used as potential targets. In $\mathrm{AD}, \mathrm{Ca}^{2+}$ dysregulation is present in many of the different compartments within neurons. In the plasma membrane, voltage-gated $\mathrm{Ca}^{2+}$ channels (VGCCs) and receptor operated $\mathrm{Ca}^{2+}$ channels, including $\mathrm{N}$-methyl-D-aspartate receptors (NMDARs) and nicotinic acetylcholine receptors (nAChRs), allow for the influx of $\mathrm{Ca}^{2+}$ ions into the neuron after depolarization or ligand binding, respectively. Both $\mathrm{A} \beta$ and tau overactivate these channels and increase their function (A). In the endoplasmic reticulum (ER), $\mathrm{Ca}^{2+}$ is released via ryanodine receptors (RyRs) and inositol 1,4,5-trisphosphate receptors $\left(\mathrm{IP}_{3} \mathrm{Rs}\right)$ to the cytosol after stimulation. $\mathrm{Ca}^{2+}$ is then extruded by the sarco-endoplasmic reticulum ATPase (SERCA) pump, which actively consumes ATP while bringing $\mathrm{Ca}^{2+}$ into the lumen. AD-associated presenilin (PS) mutations impair $\mathrm{IP}_{3} \mathrm{R}$ and RyR signaling, increasing $\mathrm{Ca}^{2+}$ release into the cytosol, and diminish SERCA activity, increasing cytosolic $\mathrm{Ca}^{2+}$ concentration. Following ER $\mathrm{Ca}^{2+}$ depletion, the stromal-interacting molecule (STIM) interacts with the Orai channel in the plasma membrane to activate the store-operated $\mathrm{Ca}^{2+}$ entry (SOCE) pathway. SOCE is decreased by diverse familial AD (FAD) PS mutations and by soluble A $\beta$. Lastly, in order to facilitate the communication between mitochondria and ER, contact points known as mitochondrial-associated membranes (MAMs) are established. Increased association between the ER and mitochondria and enhanced $\mathrm{Ca}^{2+}$ transfer have been observed in $\mathrm{AD}(\mathbf{B})$. In the mitochondria, the voltage-dependent anion-selective channel protein (VDAC) lets $\mathrm{Ca}^{2+}$ across the outer mitochondrial membrane (OMM), and the mitochondrial $\mathrm{Ca}^{2+}$ uniporter (MCU) complex allows the influx of $\mathrm{Ca}^{2+}$ across the inner mitochondrial membrane (IMM). $\mathrm{Ca}^{2+}$ efflux is partially managed by the $\mathrm{Na}^{+} / \mathrm{Ca}^{2+}$ exchanger (NCLX). Both $\mathrm{A} \beta$ and tau (phospho-tau, p-tau) have been found in mitochondria. Elevated mitochondrial $\mathrm{Ca}^{2+}$ levels and decreased NCLX activity have been observed in AD (C). In the lysosome, the $\mathrm{P} / \mathrm{Q}$ type VGCCs in their membrane regulate $\mathrm{Ca}^{2+}$ efflux into the cytosol, while the V-ATPase and $\mathrm{Ca}^{2+} / \mathrm{H}^{+}$exchanger are in charge of lysosomal $\mathrm{Ca}^{2+}$ refilling (D). Additionally, A $\beta$ and tau accumulate extracellularly and intracellularly, respectively, and lead to loss of dendritic spine density and synaptic function. 


\subsection{Targeting Plasma Membrane Receptors and Cytosolic $\mathrm{Ca}^{2+}$}

Proper intracellular $\mathrm{Ca}^{2+}$ homeostasis is crucial for many neuronal functions. Disruption of this homeostasis might be one of the main mechanisms via which $\mathrm{A} \beta$ and tau exert their neurotoxicity. The main plasma membrane channels involved in neuronal $\mathrm{Ca}^{2+}$ influx from the extracellular space are voltage-gated $\mathrm{Ca}^{2+}$ channels (VGCCs), which allow $\mathrm{Ca}^{2+}$ influx following neuronal depolarization, and receptor-operated $\mathrm{Ca}^{2+}$ channels (ROCs), which open upon specific binding of the agonist, with NMDARs among the most important examples.

Toxic $A \beta$ increases cytosolic $\mathrm{Ca}^{2+}$, which may affect a variety of enzymes (such as proteases or phosphatases), promote cytoskeletal modifications, cause the generation of free radicals, or trigger neuronal apoptosis [29]. It has been proposed that $A \beta$ can overactivate channels and/or form pores in the cytosolic plasma membrane, allowing massive influx of $\mathrm{Ca}^{2+}$ from the extracellular space and increasing the overall $\mathrm{Ca}^{2+}$ levels in the cytosol, severely limiting normal cellular function [30,31]. $A \beta$ potentiates $\mathrm{Ca}^{2+}$ influx through VGCCs, particularly L-type VGCCs. Excessive $\mathrm{Ca}^{2+}$ influx through these channels has been observed in cultured neurons following $\mathrm{A} \beta$ exposure and was shown to be blocked by the L-type VGCC inhibitor nimodipine [32]. This phenomenon, however, was not observed in brain slices from AD mouse models [33]. In addition, $\mathrm{AD}$ patients taking L-type VGCCs inhibitors such as nilvadipine (NILVAD multicenter trial) showed reduced A $\beta$ levels but no improvement in cognitive decline [34,35]. Acute application of tau aggregates has also been observed to increase cytosolic $\mathrm{Ca}^{2+}$ and elevate reactive oxygen species (ROS) production via nicotinamide adenine dinucleotide phosphate (NADPH), an effect that can be prevented by nifedipine and verapamil, both L-type VGCC inhibitors [36]. This suggests that tau fibrils could also incorporate into the cell membrane to activate VGCCs and lead to neuronal dysfunction [36].

CALHM1 $\left(\mathrm{Ca}^{2+}\right.$ homeostasis modulator protein 1$)$ is a $\mathrm{Ca}^{2+}$ channel highly expressed in neurons in the hippocampus that allows cytosolic $\mathrm{Ca}^{2+}$ influx in response to decreases in extracellular $\mathrm{Ca}^{2+}$ [37]. Its activation triggers different kinase signaling cascades in neurons. The CALMH1 polymorphism P86L has been proposed as a risk factor for late-onset SAD [9,37], an argument that has been challenged by other groups $[38,39]$. Nevertheless, increased levels of $A \beta$ have been observed in transfected cells expressing the P86L polymorphism, suggesting a role for CALMH1 in AD [37]. Additionally, the P86L polymorphism alters the channel permeability to $\mathrm{Ca}^{2+}$ [37]. A recent study demonstrated that CALHM1 deficiency in mice leads to cognitive and neuronal deficits, which manifest memory impairment and hippocampal long-term potentiation (LTP) [40], pointing to CALHM1 as a potential treatment target in AD.

NMDARs are a subfamily of ionotropic glutamate receptors involved in the excitatory synaptic transmission and synaptic plasticity of the brain. Specific types of NMDARs are much more permeable to $\mathrm{Ca}^{2+}$ than other ionotropic glutamate receptors and are often implicated in neuronal pathophysiology. NMDARs are mainly composed of GluN2A and GluN2B in the brain areas most affected in AD [41]. Extra-synaptic GluN2B-containing NMDARs have been associated with excitotoxicity (the excessive neuronal death induced by cellular $\mathrm{Ca}^{2+}$ overload due to excessive stimulation of glutamate receptors) and the toxic effect of $\mathrm{A} \beta$ oligomers in $\mathrm{AD}[42,43]$. For this reason, selective GluN2B subunit antagonists may be a strategy to prevent synaptic dysfunction in $A D . A \beta_{42}$ peptides interact with NMDARs, potentiating their activity and leading to increased $\mathrm{Ca}^{2+}$ influx, thus contributing to the synapse loss observed in AD [44,45]. Additionally, as demonstrated in mouse models of AD, glutamate-induced excitotoxicity is inhibited by tau reduction [46] and exacerbated by tau overexpression [47,48]. In turn, glutamate-induced excitotoxicity increases tau expression [49] and phosphorylation [50], while activation of extra-synaptic NMDAR leads to tau overexpression, neuronal degeneration, and cell loss [51]. Memantine-a weak NMDAR antagonist-is one of the two FDA-approved drugs to treat AD patients and the only NMDAR antagonist [23]. It provides modest improvements to memory and cognitive performance in moderate to severe AD patients [52,53]. Memantine restricts excessive $\mathrm{Ca}^{2+}$ influx, thus reducing neuronal excitotoxicity, and, due to its low activity, the basal NMDAR 
function is preserved. Memantine has also shown neuroprotective effects against oxidative stress, neuroinflammation, and tau phosphorylation $[54,55]$.

Ionotropic neuronal nicotinic acetylcholine receptors (nAChRs) respond to the neurotransmitter acetylcholine (ACh) and to drugs such as the agonist nicotine. They are permeable to $\mathrm{Na}^{+}, \mathrm{K}^{+}$, and $\mathrm{Ca}^{2+}$. The nAChRs expressing the $\alpha 7$ subunit have the highest conductance for $\mathrm{Ca}^{2+}$ and are found in brain regions most susceptible to $\mathrm{AD}$ [56]. In the basal forebrain, cholinergic neuronal loss and decreased levels of ACh mediate cholinergic impairment, which eventually leads to short-term memory loss [57-59]. The loss of cholinergic innervation in early AD led to the "cholinergic hypothesis of $\mathrm{AD}^{\prime \prime}$ [3]. Galantamine and rivastigmine (for use in mild to moderate AD) and donepezil (in mild to severe $\mathrm{AD}$ ) are the cholinesterase inhibitors FDA-approved to treat AD [23]. These drugs act by increasing ACh levels, which delay the progression of $\mathrm{AD}$ through $\mathrm{Ca}^{2+}$-dependent mechanisms. Furthermore, supplemented with memantine, it has been proposed that this combination could provide greater benefits on behavior, cognition, and global outcomes in $\mathrm{AD}$ [60].

Exposure of hippocampal and cortical neurons to tau also increased intracellular $\mathrm{Ca}^{2+}$ levels through muscarinic receptors [61]. Interestingly, $\mathrm{Ca}^{2+}$ activates many kinases, including those responsible for tau phosphorylation—such as glycogen synthase kinase $3 \beta$ (GSK3 $\beta$ ) -and, therefore, $\mathrm{Ca}^{2+}$ dyshomeostasis may increase tau phosphorylation and NFT formation [62]. Given that tau pathology correlates better with cognitive impairments than $A \beta$ deposition, tau targeting is expected to be more effective once clinical symptoms emerge [63]. It has long been known that tau-expressing cells secrete normal and pathological tau [64], which can be taken up by other cells, seeding and spreading tau pathology [4,65-67]. Led by immunotherapy approaches, the efforts to target tau with therapeutics focus on reducing tau pathology by limiting the spread of extracellular tau across brain regions [68]. Anti-tau immunotherapy has shown potential in numerous clinical studies. Both active and passive tau immunization seem to offer a promising option by reducing tau pathology [69]. Active tau immunization, however, seems to elicit a risk of adverse immune reactions from targeting the normal protein. Other tested approaches involve reducing tau expression (with small interfering RNA or antisense oligonucleotides; siRNA and ASOs, respectively), targeting tau modifications, reducing tau aggregation, and stabilizing microtubules. Preventing or reducing pathologic tau has been shown to improve cognitive and motor impairments in animal models with neurofibrillary pathology, and several tau antibodies and vaccines have been tested in preclinical studies in the last years. Immunotherapy is currently at the stage of drug development (recently reviewed in [68-70]), and, as of today, eight humanized tau antibodies and two tau vaccines are under clinical trial for AD or frontotemporal dementia [71] (www.alzforum.org).

The use of intravital imaging and transgenic mouse models of AD have allowed for direct observation of cytosolic $\mathrm{Ca}^{2+}$ dysregulation. In vivo, neuronal cytosolic $\mathrm{Ca}^{2+}$ dyshomeostasis is more likely to be observed in the vicinity of amyloid $\beta$ plaques, but is detectable in neurons throughout the cortex [15]. Higher $\mathrm{Ca}^{2+}$ levels were observed in neurons close to amyloid plaques in a commonly used mouse model of cerebral amyloidosis $\left(\mathrm{APP}_{\mathrm{Swe}} \mathrm{XPS1} \triangle \mathrm{E} 9, \mathrm{APP} / \mathrm{PS} 1\right)$ [15], but only after plaque deposition and not before. Cytosolic $\mathrm{Ca}^{2+}$ overload was absent in mice harboring only the PS1 mutation (typically lacking plaque deposition). The mechanisms of $\mathrm{Ca}^{2+}$ dysregulation involved activation of calcineurin $(\mathrm{CaN}), \mathrm{a} \mathrm{Ca}^{2+} / \mathrm{calmodulin}$-dependent protein phosphatase sensitive to subtle rises in intracellular $\mathrm{Ca}^{2+}$ levels, and whose activation induces long-term depression (LTD). $\mathrm{Ca}^{2+}$ dysregulation in neurites was linked to neurodegeneration (neuritic blebbing and beading), which can be partially prevented by inhibiting $\mathrm{CaN}$ [15]. Elevated $\mathrm{Ca}^{2+}$ levels in the neurites impair synapses, by increasing the frequency of spontaneous synaptic potentials and reducing plasticity. In addition, pathological increases in neuronal network activity-observed as increased frequencies of somatic $\mathrm{Ca}^{2+}$ transients-potentiate $\mathrm{A} \beta$ release into the extracellular space [72,73]. In the APP23/PS45 mouse model of AD (overexpressing mutant $\mathrm{APP}_{\mathrm{Swe}}$ and mutant $\mathrm{PS} 1_{\mathrm{G} 348 \mathrm{~A}}$ ), neuronal hyperactivity was observed around amyloid plaques in the cortex, only after plaque deposition [14]. Hyperactive neurons, however, were found in the CA1 region of the hippocampus in pre-depositing animals [13]. Direct application of soluble A $\beta$ onto the 
wild-type (Wt) naïve brain increased cytosolic $\mathrm{Ca}^{2+}$ levels [12] and induced neuronal hyperactivity [13]. Acute treatment with the $\gamma$-secretase inhibitor LY-411575, which reduces soluble A $\beta$ levels, normalized the frequency of $\mathrm{Ca}^{2+}$ transients prior to plaque deposition [13].

Interestingly, $\mathrm{AD}$ patients are more prone to developing epileptic seizures [74]. Blocking network hyperactivity with the antiepileptic drug levetiracetam improves learning and memory, reverses behavioral abnormalities, and reverts synaptic deficits in the hippocampus in an AD mouse model [75]. In the same way, it has been observed that tau is implicated in neuronal circuit deficits in mouse models of $\mathrm{AD}$ expressing both $\mathrm{A} \beta$ and tau. Tau effects dominate those of $\mathrm{A} \beta$ and are mostly dependent on the presence of soluble tau [16]. According to the authors, this dramatic effect could suggest a possible cellular explanation contributing to disappointing results of anti-A $\beta$ therapeutic trials. This abnormal network activity and its resultant AD-related cognitive deficits in mice point to neuronal hyperactivity as a promising therapeutic target in $\mathrm{AD}$.

Aducanumab is a high-affinity, fully human immunoglobulin G1 (IgG1) monoclonal antibody that selectively binds to aggregated $\mathrm{A} \beta$ fibrils and soluble oligomers (and not monomers) in the brain parenchyma [25]. It was shown that it could ameliorate $\mathrm{Ca}^{2+}$ dysregulation in $\mathrm{AD}$. Using multiphoton microscopy and $\mathrm{a} \mathrm{Ca}^{2+}$ reporter, it was observed that a single topical application of the antibody onto the brain surface of mice depositing amyloid plaques (Tg2576 AD model) led to a reduction in existing amyloid deposits [76]. Peripheral administration of the antibody over a period of 6 months rescued $\mathrm{Ca}^{2+}$ overload in transgenic neurites, restoring them to control levels within 2 weeks. The authors suggested that aducanumab exerted its function by targeting amyloid deposits, including soluble oligomeric A $\beta$ [76]. In March 2019, the termination of all aducanumab clinical trials was announced after an interim analysis of EMERGE and ENGAGE trials predicted the phase III placebo-controlled studies would not meet their primary end points. However, in a subsequent analysis of a larger dataset from the EMERGE trial, aducanumab met the primary end point, and the FDA accepted the aducanumab application for review [77]. If the case is approved, aducanumab would be the first drug to combat the root causes of AD.

\subsection{Targeting $E R \mathrm{Ca}^{2+}$ and $S O C E$}

The ER is an important subcellular organelle involved in protein synthesis, modification, and folding. Additionally, it is a dominant $\mathrm{Ca}^{2+}$ reservoir in the cell, critical for maintaining intracellular $\mathrm{Ca}^{2+}$ levels [27]. $\mathrm{Ca}^{2+}$ is released from the ER after activation of either inositol 1,4,5-trisphosphate receptors $\left(\mathrm{IP}_{3} \mathrm{Rs}\right)$ or ryanodine receptors (RyRs). $\mathrm{Ca}^{2+}$ efflux from the ER modulates a range of neuronal processes, including regulation of axodendritic growth and morphology or synaptic vesicle release [78]. The sarco-endoplasmic reticulum ATPase (SERCA) pump, which actively consumes ATP, is important for extruding $\mathrm{Ca}^{2+}$ into the ER lumen, where it is sequestered by binding to proteins such as calsequestrin and calretinin, priming this organelle as a critical component of $\mathrm{Ca}^{2+}$ buffering.

Impaired $\mathrm{IP}_{3} \mathrm{R}$ signaling in the ER was an early discovery in AD. It was shown that human cells from FAD patients exhibited enhanced $\mathrm{Ca}^{2+}$ release in response to $\mathrm{IP}_{3} \mathrm{R}$-generating stimuli [79]. Fibroblasts from asymptomatic members of AD families [80], as well as PS1 knock-in mice and other presymptomatic AD mouse models, showed the same enhancement [81]. These observations suggested that FAD mutations contribute to $\mathrm{Ca}^{2+}$ dysregulation, even before pathology deposition or cognitive impairments were evident. A reduction in $\mathrm{IP}_{3} \mathrm{R}$ expression can normalize $\mathrm{Ca}^{2+}$ homeostasis and restore hippocampal LTP in mouse models of AD [82]. PSs are transmembrane proteins found in the ER membranes and form the catalytic core of the $\gamma$-secretase complex that processes APP and other type 1 transmembrane proteins, such as Notch $[83,84]$. PSs are essential for learning and memory, as well as neuronal survival during aging in the murine cerebral cortex $[85,86]$. Mutations in PSs have been shown to affect APP processing, leading to increased production of the more hydrophobic neurotoxic form $A \beta_{42}$ [87-89] or increasing the $A \beta 42 / 40$ production ratio [90]. It has also been proposed that PSEN mutations cause a loss of presenilin function in the brain, triggering neurodegeneration and dementia in FAD [91]. Mutations in PS1 and PS2 might stimulate $\mathrm{IP}_{3} \mathrm{Rs}$, leading to exaggerated $\mathrm{Ca}^{2+}$ 
release through these channels [79-81]. An alternative hypothesis suggested that PSs function as passive low-conductance leak channels in the ER membrane. AD-associated PS mutations might impair this leak function, resulting in $\mathrm{ER} \mathrm{Ca}^{2+}$ overload [92] and leading to exaggerated increases in cytosolic $\mathrm{Ca}^{2+}$ upon stimulation of $\mathrm{Ca}^{2+}$ release. However, these observations have not been supported by other groups [93,94], and, despite extensive research, this subject is still a matter of controversy. Recently, it was proposed that the ER-based transmembrane and coiled-coil domain TMCO1 could be responsible for the ER $\mathrm{Ca}^{2+}$ leak [95].

RyR $\mathrm{Ca}^{2+}$ dysregulation was also observed before the histopathology and cognitive decline in AD. Both human brain tissue from AD patients and AD mouse models have shown increased expression of RyR (particularly $\mathrm{RyR}_{2}$ ) in affected brain regions in $\mathrm{AD}$ [96]. Exaggerated $\mathrm{Ca}^{2+}$ release from RyR has been related to impaired neurophysiology and synaptic signaling events, contributing to memory impairment in AD $[33,97,98]$. The FAD PS mutations also exaggerate $\mathrm{Ca}^{2+}$ release through the RyR, as a result of either increased expression of RyRs or sensitization of the channel activity $[99,100]$. Furthermore, RyR-mediated $\mathrm{Ca}^{2+}$ release upregulates secretases, increasing APP cleavage, $A \beta$ fragments, and plaque deposition, and its blockage leads to $A \beta$ reduction and improved memory impairment [101]. RyRs can also themselves be activated by $\mathrm{Ca}^{2+}$, which amplify $\mathrm{IP}_{3} \mathrm{R}$ activity via $\mathrm{Ca}^{2+}$-induced $\mathrm{Ca}^{2+}$ release mechanisms [102]. Additionally, $\mathrm{A} \beta$ aggregates themselves trigger $\mathrm{ER} \mathrm{Ca}^{2+}$ release through $\mathrm{IP}_{3} \mathrm{Rs}$ and RyRs $[103,104]$. Recently, stabilization of $\mathrm{RyR}_{2}$ macromolecular complex by S107 (Rycal) - a benzothiazepine that prevents the dissociation calstabin 2 from the $\mathrm{RyR}_{2}$ complex-showed therapeutic potential in vitro and in mouse models of $\mathrm{AD}$ in vivo. Application or administration of $\mathrm{S} 107$ reversed $\mathrm{ER} \mathrm{Ca}{ }^{2+}$ leak, reduced APP cleavage and $\mathrm{A} \beta$ production, and restored synaptic plasticity and cognitive deficits $[105,106]$.

It has been found that, in cells lacking PS1, PS2, or PS1/2, or cells expressing either PS2 or FAD-PS2, SERCA activity is diminished, resulting in increased cytosolic $\mathrm{Ca}^{2+}$ [107]. Conversely, other studies have shown that mutations in PS influence SERCA by accelerating $\mathrm{Ca}^{2+}$ sequestration via ATPase [108], leading to an overfilled ER. In any case, these data suggest that normal PSs are required for normal SERCA functioning and suggest that PSs are a candidate target for development of therapeutics, independent of their role in APP processing.

Increased $\mathrm{Ca}^{2+}$ release from intracellular $\mathrm{ER} \mathrm{Ca}^{2+}$ stores might exacerbate disease-mediated pathology. Accordingly, dantrolene, a negative allosteric modulator of RyR-and its central nervous system (CNS)-penetrant version Ryanodex - has been shown to reduce amyloid pathology, normalize $\mathrm{ER} \mathrm{Ca}^{2+}$ homeostasis, restore synaptic structure and density, normalize synaptic plasticity, and improve behavioral performance in mouse models of $\operatorname{AD}[101,109,110]$. This builds on RyR as a therapeutic target for $\mathrm{AD}$, and further emphasizes the role of dysregulated $\mathrm{ER} \mathrm{Ca}^{2+}$ as a key component in the AD pathogenesis.

ER $\mathrm{Ca}^{2+}$ depletion triggers a sustained extracellular $\mathrm{Ca}^{2+}$ influx to the cytosol through the store-operated $\mathrm{Ca}^{2+}$ entry (SOCE) pathway by activating STIM (stromal-interacting molecule) protein-which senses low $\mathrm{Ca}^{2+}$ concentration upon depletion of the ER stores-and plasma membrane channels Orai and TRPC (transient receptor potential canonical) [111]. Two forms of STIM are expressed in the brain (STIM1, predominantly in the cerebellum, and STIM2 in the hippocampus and cortex) [112]. SOCE refills the ER, keeping it ready for the next ER $\mathrm{Ca}^{2+}$ signal [113]. Disrupted SOCE has been observed in AD. SOCE is decreased by diverse FAD PS mutations $[114,115]$ and in the presence of soluble $A \beta$ [116]. It has also been proposed that SOCE deficits may be due to the decreased expression of STIM1 and/or STIM2 in FAD-linked PS1 mutations [117]. Related to this, overexpression of the dominant negative PS1 variant potentiates SOCE [118]. It has also been proposed that SOCE deficits might result from overfilled ER $\mathrm{Ca}^{2+}$ stores [114]. These findings, however, are inconsistent, as other groups have observed no differences or decreased ER Ca ${ }^{2+}$ concentration in mutant PS expressing cells $[11,93,107]$. Recently, it has been proposed that neuronal SOCE is required for maintaining the morphology of mushroom spines, modulating $A \beta$ production and promoting memory functions $[117,119] . \mathrm{Ca}^{2+}$ entry via SOCE activates $\mathrm{Ca}^{2+} / \mathrm{CaM}$-dependent kinase II (CamKII), which is upstream of gene transcription 
for maintenance of mature spines. Attenuated SOCE-mediated $\mathrm{Ca}^{2+}$ influx might reduce CaMKII activity while inducing destabilization of mushroom spines. This can reduce LTP-mediated memory formation [117]. Attenuated SOCE may also lead to inadequate ER refill, which might induce neuronal cell death via apoptosis $[120,121]$. STIM2 overexpression in AD models restores spine morphology, implicating SOCE in AD [122] and suggesting that targeting SOCE in AD may avoid or restore dendritic spine loss. Additionally, it was recently found that expression of TRPC1, a subfamily of TRPCs, is decreased in AD cells and mouse models. While deletion of TRPC1 did not impair cognitive function or lead to cell death in physiological conditions, it did exacerbate memory deficits and increase neuronal apoptosis induced by A $\beta$. On the contrary, overexpression of TRPC 1 inhibited A $\beta$ production and decreased apoptosis [123]. Together, these studies suggest another mechanistic target for therapeutic development within the $\mathrm{Ca}^{2+}$ hypothesis of $\mathrm{AD}$.

\subsection{Targeting Mitochondrial $\mathrm{Ca}^{2+}$}

Mitochondria are crucial organelles that provide energy to the cell in the form of adenosine triphosphate (ATP) via the process of oxidative phosphorylation. Mitochondria form a dynamic tubular network that extends throughout the cytosol, undergoing fusion and fission, which regulates the morphology and structure of the mitochondrial network [124]. Neurons rely strictly on mitochondria to produce ATP, with mitochondria being recruited in areas like synapses, where high energy is required. Mitochondria also buffer $\mathrm{Ca}^{2+}$ and shape its signal [125], which is involved in neurotransmission and maintenance of the membrane potential along the axon. At the synaptic level, mitochondria regulate the $\mathrm{Ca}^{2+}$ levels necessary for synaptic functions [126]. Mitochondrial $\mathrm{Ca}^{2+}$ uptake activates some dehydrogenases at the electron transport chain (ETC), activating mitochondrial respiration and ATP production [127]. The electrochemical gradient created by the ETC allows mitochondria to take up $\mathrm{Ca}^{2+}$. This mitochondrial $\mathrm{Ca}^{2+}$ participates in signal transduction and the production of energy. Mitochondria contain two major membranes, the outer mitochondrial membrane (OMM), which contains voltage-dependent anion-selective channel protein (VDAC), permeable to most molecules, and the inner mitochondrial membrane (IMM), which is impermeable to molecules and ions, unless they contain specific channels or transporters.

$\mathrm{Ca}^{2+}$ is taken up into the mitochondrial matrix through the mitochondrial $\mathrm{Ca}^{2+}$ uniporter (MCU) complex, a highly $\mathrm{Ca}^{2+}$-sensitive ion conductance channel $[128,129]$. The MCU is a macromolecular complex of proteins, which includes the pore and several regulatory subunits. It is ubiquitously expressed among organisms and defines the pore domain of the complex [128]. Two other proteins participate in the $\mathrm{Ca}^{2+}$ permeant pore: $\mathrm{MCUb}$, whose expression is restricted to most vertebrates [130,131], and the essential MCU regulator (EMRE) [132]. The response of the MCU to extramitochondrial $\mathrm{Ca}^{2+}$ is regulated by the mitochondrial $\mathrm{Ca}^{2+}$ uptake (MICU) family of proteins, which are in the intermembrane space. MICU1 and MICU2 act as $\mathrm{Ca}^{2+}$ sensors, each with two $\mathrm{Ca}^{2+}$-binding EF-hand motifs that confer sensitivity to $\mathrm{Ca}^{2+}$ [133]. MICU1 and MICU2 also act as gatekeepers of MCU [134], with MICU1 getting involved when the extramitochondrial $\mathrm{Ca}^{2+}$ concentration is high, activating the channel open state. At low concentrations, the main player seems to be MICU2, leading to minimal accumulation of $\mathrm{Ca}^{2+}$ within mitochondria $[135,136]$, thus preventing mitochondrial $\mathrm{Ca}^{2+}$ overload at resting conditions. MICU3, a paralog of MICU1 and MICU2, is mainly expressed in the CNS [137], and has been proposed to enhance mitochondrial $\mathrm{Ca}^{2+}$ uptake in neurons [138]. In regulating the MCU pore, the mitochondrial $\mathrm{Ca}^{2+}$ uniporter regulator 1 (MCUR1) also plays a role [139]. It has been suggested as a necessary player in MCU-mediated mitochondrial $\mathrm{Ca}^{2+}$ uptake. The small $\mathrm{Ca}^{2+}$-binding mitochondrial carrier protein (SCaMC, also known as SLC25A23) [140] seems to also participate in the mitochondrial $\mathrm{Ca}^{2+}$ uptake by interacting with MCU and M1CU1.

Mitochondrial $\mathrm{Ca}^{2+}$ efflux occurs via the $\mathrm{Na}^{+} / \mathrm{Ca}^{2+}$ exchanger (NCLX) [141] and leucine zipperand EF hand-containing transmembrane protein 1 (Letm1), located at the IMM [142]. Excessive $\mathrm{Ca}^{2+}$ in the mitochondrial matrix induces the activation of the mitochondrial permeability transition pore (mPTP) and allows the release of $\mathrm{Ca}^{2+}$ ions and small molecules such as cytochrome c [143]. 
Mitochondrial $\mathrm{Ca}^{2+}$ levels are tightly regulated since excessive levels of $\mathrm{Ca}^{2+}$ within mitochondria, i.e., mitochondrial $\mathrm{Ca}^{2+}$ overload, result in the impairment of mitochondrial function, suppression of ATP production, increase in reactive oxygen species (ROS) production, and $\mathrm{mPTP}$ opening. This can lead to caspase activation and cell death via apoptosis [144].

Mitochondrial function has long been considered one of the intracellular processes compromised at the early stages in AD and likely in other neurodegenerative diseases. Moreover, the "mitochondrial cascade hypothesis" was proposed to explain the onset of SAD [145], which posits that mitochondrial dysfunction is the primary process to trigger the cascade of events that lead to late-onset AD. Even though the validity of this hypothesis has yet to be demonstrated, numerous mitochondrial functions are disrupted in AD [146], including mitochondrial morphology and number [147], oxidative phosphorylation, mitochondrial membrane potential, ROS production [148], mitochondrial DNA (mtDNA) oxidation and mutation [149], mitochondrial-ER contacts [150], and mitochondrial dynamics, including mitochondrial transport along the axon and mitophagy [151]. Additionally, both A $\beta$ and tau have been found in mitochondria. $A \beta$ is imported to mitochondrial matrix via translocase of the outer membrane (TOM) [152], and a fraction of intracellular tau has been found within the inner mitochondrial space [153]. Once in mitochondria, they interact with specific intramitochondrial targets, leading to the dysfunction of the organelle. Furthermore, tau accumulation in mitochondrial synaptosomes has been proposed to correlate with synaptic loss in AD brains [154].

Mitochondrial $\mathrm{Ca}^{2+}$ dysregulation is considered a fingerprint of AD. Mitochondrial $\mathrm{Ca}^{2+}$ overload can be a result of three different processes: (i) increased mitochondrial $\mathrm{Ca}^{2+}$ influx (following $\mathrm{Ca}^{2+}$ influx from extracellular space or $\mathrm{Ca}^{2+}$ transfer from ER), (ii) decreased mitochondrial $\mathrm{Ca}^{2+}$ efflux through NCLX, or (iii) reduced mitochondrial $\mathrm{Ca}^{2+}$ buffering. Neurotoxic $\mathrm{A} \beta$ can lead to mitochondrial $\mathrm{Ca}^{2+}$ overload, as shown in in vitro and in vivo models [155-157]. Primary neurons in culture exposed to $A \beta$ oligomers triggered mitochondrial $\mathrm{Ca}^{2+}$ overload, leading to $\mathrm{MPTP}$ opening, release of cytochrome c, and cell death via mitochondrial-mediated apoptosis [156]. Additionally, studies in mouse neuroblastoma N2a cells co-transfected with the Swedish mutant APP and $\Delta 9$ deleted PS1 showed similar mitochondrial impairment, evidenced by the increased mitochondrial apoptotic pathway and caspase-3 activity [158]. Furthermore, A $\beta$ can interact with cyclophilin D-a regulator of $\mathrm{MPTP}$ - and promote the release of cytochrome $\mathrm{c}$ through the opening of MPTP [159]. This causes neuronal injury and decline of cognitive functions, as shown in a mouse model of AD. Genetic deletion of CypD in Tg AD mice rescues mitochondrial impairment and improves learning and memory [160], suggesting that CypD could represent a potential therapeutic target in AD.

Recently, we showed mitochondrial $\mathrm{Ca}^{2+}$ overload in a mouse model of cerebral amyloidosis (APP/PS1). Using in vivo multiphoton imaging and a ratiometric $\mathrm{Ca}^{2+}$ reporter, we demonstrated increased levels of mitochondrial $\mathrm{Ca}^{2+}$ following $\mathrm{A} \beta$ deposition, which preceded neuronal cell death. Moreover, naturally secreted soluble oligomers applied to the healthy brain of Wt mice also increased mitochondrial $\mathrm{Ca}^{2+}$ levels, a process that could be prevented by MCU inhibition with the specific channel blocker Ru360 [157]. We also showed, for the first time, that the expression of mitochondrial $\mathrm{Ca}^{2+}$ transport-related genes in brain tissue from AD patients was impaired compared to control cases. In particular, genes involved in mitochondrial $\mathrm{Ca}^{2+}$ uptake (MCU complex) were downregulated, whereas the only one encoding for $\mathrm{Ca}^{2+}$ efflux (NCLX) was upregulated, suggesting a compensatory response to prevent mitochondrial $\mathrm{Ca}^{2+}$ overload [157]. However, others reported that different techniques used for evaluating expression showed conflicting results [161]. Another mechanism proposed for mitochondrial $\mathrm{Ca}^{2+}$ overload in $\mathrm{AD}$ is impairment of mitochondrial $\mathrm{Ca}^{2+}$ efflux. Loss of NCLX expression and functionality has also been suggested in AD, whereas genetic rescue of NCLX expression in neurons restored cognitive decline and cellular impairment in transgenic mouse models of AD [161]. Additionally, the more general cytosolic $\mathrm{Ca}^{2+}$ overload observed in vivo (as previously cited) may contribute to the observed mitochondrial $\mathrm{Ca}^{2+}$ overload. These observations suggest that restoring mitochondrial $\mathrm{Ca}^{2+}$ levels in $\mathrm{AD}$ could be a promising new therapeutic target against $\mathrm{AD}$. 
It has been previously proposed that nonsteroidal anti-inflammatory drugs (NSAIDs) may help in preventing the cognitive decline associated with aging [162]. Unfortunately, results from several clinical trials have given rather pessimistic results [163-165], partly due to inadequate CNS drug penetration of existing NSAIDs, suboptimal doses, unknown molecular targets (and, therefore, unknown pharmacodynamics), and toxicities. Nevertheless, in vitro studies have shown that NSAIDs such as salicylate and the enantiomer $(R)$-Flurbiprofen lacking anti-inflammatory activity, at low concentrations, are able to depolarize mitochondria and inhibit the driving force for mitochondrial $\mathrm{Ca}^{2+}$ uptake $[166,167]$. They act as mild mitochondrial uncouplers without altering cytosolic $\mathrm{Ca}^{2+}$ levels. This mild mitochondrial depolarization was able to prevent NMDA- and A $\beta$-induced mitochondrial $\mathrm{Ca}^{2+}$ uptake and cell death $[155,156,168]$. These results point to mitochondrial $\mathrm{Ca}^{2+}$ as a key player in $\mathrm{A} \beta$-driven neurotoxicity and suggest a new mechanism of neuroprotection by NSAIDs independent of their anti-inflammatory activity. Another compound, TG-2112x, has been recently suggested as neuroprotective and proposed as a new therapeutic opportunity. Tg-2112x partially inhibits mitochondrial $\mathrm{Ca}^{2+}$ uptake without affecting the mitochondrial membrane potential or mitochondrial bioenergetics, protecting neurons against glutamate excitotoxicity [169].

Abnormal tau hyperphosphorylation also influences mitochondrial transport along the neuronal axon, which leads to a reduction in and impairment of mitochondria at the presynaptic terminal with detrimental consequences and eventual cell death $[170,171]$. In vitro and in vivo studies have shown that tau dysregulates $\mathrm{Ca}^{2+}$ homeostasis in mitochondria. Mitochondrial $\mathrm{Ca}^{2+}$ buffering and homeostasis are disrupted in cells overexpressing tau and those exposed to extracellular tau aggregates [61,172]. Additionally, basal mitochondrial $\mathrm{Ca}^{2+}$ levels have been shown to be elevated in patient-derived human induced pluripotent stem cell (iPSC) neurons expressing a tau mutation, likely due to the inhibition of NCLX by tau [173]. Elevation in mitochondrial $\mathrm{Ca}^{2+}$ levels by tau also increased the vulnerability to $\mathrm{Ca}^{2+}$-induced cell death [173]. Phosphorylated tau has also been found to interact with VDAC in AD brains, leading to mitochondrial dysfunction [174].

Mitochondria and ER membranes are juxtaposed and establish contact points known as mitochondrial-associated membranes (MAMs). They are dynamic lipid rafts enriched in cholesterol and sphingomyelin, as well as in proteins associated with $\mathrm{Ca}^{2+}$ dynamics $[175,176]$. MAMs allow for communication between ER and mitochondria, including metabolic pathways and $\mathrm{Ca}^{2+}$ transfer from ER to mitochondria [177]. Increased contacts between ER and mitochondria have been found in human fibroblast cells derived from FAD patients, human brain tissue, and AD mouse models $[178,179]$. An increased association between the ER and mitochondria has also been observed in a Tg mouse model of tauopathy [180]. Increased contact promotes mitochondrial bioenergetics, but excessive $\mathrm{Ca}^{2+}$ transfer can contribute to mitochondrial $\mathrm{Ca}^{2+}$ overload and suppression of normal mitochondrial functions, and $\mathrm{A} \beta$ oligomers have been found to induce massive $\mathrm{Ca}^{2+}$ transfer from $\mathrm{ER}$ to mitochondria [116,181-183].

Mitochondria-targeted protective compounds that prevent or minimize mitochondrial dysfunction could represent potential therapeutic strategies in the prevention or treatment of AD. However, several compounds targeting mitochondrial function have been tested in AD without a favorable outcome [184]. Nevertheless, the idea of $\mathrm{AD}$ as a multifactorial disease is widespread, and mitochondria as a therapeutic target combined with other medications is emerging as a valid therapy for $\mathrm{AD}$. The list of pharmacologic approaches that directly target mitochondria includes antioxidants (such as vitamin $\mathrm{E}$ and $\mathrm{C}$, coenzyme Q10, mitoQ, and melatonin) and phenylpropanoids (such as resveratrol, quercetin, or curcumin) [185]. Antioxidants are generally used to decrease oxidative stress and slow the progression of symptoms that generally accompany AD. Antioxidants such as coenzyme Q10 and mitoquinone mesylate (MitoQ) are antioxidants that directly target mitochondria [186]. Currently, there is a small clinical trial testing MitoQ on cerebrovascular blood flow in AD [187]. The Szeto-Schiller (SS) tetrapeptides, an alternative type of antioxidants that target mitochondria, are small molecules that can reach the mitochondrial matrix and act as antioxidants [188]. Specifically, SS31 (also known as elamipretide) selectively binds to cardiolipin and promotes electron transport while optimizing mitochondrial ATP synthesis [189]. 
In addition, SS31 inhibits mitochondria swelling and oxidative cell death. In mouse models of cerebral amyloidosis, it was shown that SS31 reduces A $\beta$ production and mitochondrial dysfunction, and enhances mitochondrial biogenesis and synaptic activity [190]. Recently, SS31 combined with the mitochondrial division inhibitor 1 (Mdivi1) was tested in vitro with a positive outcome, suggesting this combination as a possible type of mitochondria-targeted antioxidant in AD [191]. Ongoing clinical trials regarding mitochondria in AD are reviewed in $[187,192]$ and at www.clinicaltrials.gov.

\subsection{Targeting Lysosomal $\mathrm{Ca}^{2+}$}

Lysosomes are acidic organelles that participate in the endolysosomal system. They are important for autophagy and intracellular $\mathrm{Ca}^{2+}$ storage (with comparable $\mathrm{Ca}^{2+}$ levels to those of the ER) [193]. The $\mathrm{Ca}^{2+}$ transport in and out of the lysosomal lumen provides signals that modulate the fusion of autophagosomes and lysosomes. In order to maintain lysosomal $\mathrm{Ca}^{2+}$ homeostasis, lysosomes contain P/Q type VGCCs expressed in the lysosomal membrane that provide $\mathrm{Ca}^{2+}$ to the cytosol. Dysregulation in lysosomal $\mathrm{Ca}^{2+}$ release via VGCCs leads to defective autophagic fusion and flux [194]. The vacuolar-type $\mathrm{H}^{+}$-ATPase (V-ATPase) and $\mathrm{Ca}^{2+} / \mathrm{H}^{+}$exchanger are in charge of lysosomal $\mathrm{Ca}^{2+}$ refilling [195]. It has been suggested that this refilling is largely dependent on $\mathrm{ER} \mathrm{Ca}^{2+}$ [196]. V-ATPase activity predominantly maintains lysosomal $\mathrm{pH}$; however, other ion channels localized to the lysosomal membrane participate in $\mathrm{pH}$ regulation during lysosomal proteolysis, including the chloride channel CLC7 [197] and the $\mathrm{Ca}^{2+}$ channel TRPML1 (mucolipin) [198,199]. Additionally, $\mathrm{Ca}^{2+}$ microdomains generated at the mouth of these channels have been suggested to take part in the regulation of autophagy [200].

Lysosomal $\mathrm{Ca}^{2+}$ efflux has been linked to changes in lysosomal $\mathrm{pH}$. Recent reports suggested that decreased lysosomal $\mathrm{Ca}^{2+}$ in AD-linked mutations or PS1 knockout (KO) cells is a consequence of elevated lysosomal $\mathrm{pH}$ [201]. Raising lysosomal $\mathrm{pH}$ leads to autophagy defects and lysosomal $\mathrm{Ca}^{2+}$ efflux. PS1 mutant cells exhibit these defects. PS1 KO cells show deficiencies in lysosomal V-ATPase content and function, defective autophagy, and abnormal $\mathrm{Ca}^{2+}$ efflux. [201]. Reversal of lysosomal $\mathrm{pH}$ abnormalities in PS1 KO cells, but not $\mathrm{Ca}^{2+}$ efflux deficits, was sufficient to rescue these same deficits [201]. These data suggest that lysosomal $\mathrm{Ca}^{2+}$ defects are secondary to lysosomal $\mathrm{pH}$ elevation, and that lysosomal $\mathrm{Ca}^{2+}$ dyshomeostasis contributes significantly to the overall $\mathrm{Ca}^{2+}$ dysregulation observed in PS1-deficient cells. However, other studies do not support these arguments, citing that, although the autophagosome and lysosome accumulation was apparent in PS1 or PS2 cells, defective lysosome acidification was not found [202]. In addition, defects in lysosome acidification or $\mathrm{Ca}^{2+}$ homeostasis have not been observed in FAD-PS2 models [203]. On the contrary, other studies have shown both reduced cytosolic $\mathrm{Ca}^{2+}$ signal and lower ER content in FAD-PS2 models. In particular, it was proposed that FAD-PS2 decreases ER and cis-medial Golgi $\mathrm{Ca}^{2+}$ levels by reducing SERCA activity, which could lead to defective autophagosome-lysosome fusion [203]. Further studies are necessary to confirm these observations and demonstrate whether or not lysosomal $\mathrm{Ca}^{2+}$ or $\mathrm{pH}$ could be potential therapeutic targets for AD.

Autophagy is a lysosomal degradative pathway responsible for the recycling of different cellular constituents. Especially important under conditions of metabolic stress, this pathway aids in the cellular turnover of damaged or obsolete organelles in order to eliminate misfolded and aggregated proteins left behind by the ubiquitin-proteasome system [204]. Materials are engulfed within double-membrane vesicles (autophagosomes) and targeted to lysosomes for degradation of molecular components. Disruption of autophagy results in accumulation of autophagic vacuoles within swollen dystrophic neurites of affected neurons [205]. Lysosomal $\mathrm{Ca}^{2+}$ has been proposed to trigger transcriptional activation of autophagic proteins [200]. Impairment of the autophagy-lysosomal pathway has been described as a hallmark of $\mathrm{AD}$ related to lysosomal $\mathrm{Ca}^{2+}$ dyshomeostasis. This dysregulation impacts clearance of $A \beta$ and hyperphosphorylated tau, and contributes to their accumulation in the brain [206,207]. 


\section{Astrocytic $\mathrm{Ca}^{2+}$ as a Therapeutic Target in AD}

Astrocytes, the most abundant cells in the brain, are key regulators of molecular homeostasis in the nervous system. They provide trophic and metabolic support to neurons, sense and modulate neuronal network excitability, and participate in neurovascular coupling and maintenance of the blood-brain barrier [208-210]. Astrocytes do not generate action potentials, but exhibit $\mathrm{Ca}^{2+}$ transients followed by a release of gliotrasmitters-such as ATP, glutamate, or gamma-aminobutyric acid (GABA) - in response to neurotransmitters [211]. It has been proposed that the $\mathrm{Ca}^{2+}$ global signals-propagating waves-rely on $\mathrm{Ca}^{2+}$ release from the ER (mostly mediated by $\mathrm{IP}_{3} \mathrm{R}$ ). Local $\mathrm{Ca}^{2+}$ microdomains, on the other hand, result from $\mathrm{Ca}^{2+}$ influx via ionotropic receptors, TRPs, SOCE, mitochondrial $\mathrm{Ca}^{2+}$ activity, or reversed $\mathrm{Na}^{+} / \mathrm{Ca}^{2+}$ exchangers [212].

In $\mathrm{AD}$, astrocytes become activated. Reactive astrogliosis is characterized by the biochemical, functional, and morphological reshaping of astrocytes aimed at neuroprotection [213]. Reactive astrocytes upregulate activation markers such as glial fibrillary acidic protein and vimentin. Using postmortem human tissue, it has been shown that reactive astrocytes associated with plaques express higher levels of the glutamate metabotropic receptor mGluR5, which induces $\mathrm{Ca}^{2+}$ release form intracellular stores [214]. In vitro, exposure of astrocytes to $A \beta$ increases basal intracellular $\mathrm{Ca}^{2+}$ levels as a result of extracellular $\mathrm{Ca}^{2+}$ entry, release from mGluR5 and $\mathrm{IP}_{3} \mathrm{R}$, and induced $\mathrm{Ca}^{2+}$ oscillations or transients $[214,215]$. Pharmacological inhibition of $\mathrm{ER} \mathrm{Ca}^{2+}$ release blocks the $\mathrm{A} \beta$-induced astrogliosis both in cultured astrocytes and in organotypic slices [216]. As observed in co-cultures of neurons and astrocytes, the $\mathrm{A} \beta$-induced astrocytic $\mathrm{Ca}^{2+}$ transients are followed by neuronal death, suggesting that aberrant astrocytic $\mathrm{Ca}^{2+}$ signal results in neurotoxicity [217]. These results, however, are not universal, and other groups have not replicated these observations [218]. It has also been suggested that $A P O E 4$ dysregulates $\mathrm{Ca}^{2+}$ excitability in astrocytes by modifying membrane lipid composition. This phenomenon was observed in hippocampal slices from APOE3 and APOE4 mice, specifically in male mice [219], suggesting that the APOE genotype modulates $\mathrm{Ca}^{2+}$ fluxes in astrocytes in a lipid and sex-dependent manner. As demonstrated in primary cortical co-cultures of neurons and astrocytes, exposure to insoluble aggregates of tau failed to induce a $\mathrm{Ca}^{2+}$ response in astrocytes [36]. Unfortunately, little else is known about the effects of tau on astrocytic $\mathrm{Ca}^{2+}$, and further research is clearly warranted.

In the intact brain in vivo under physiological conditions, astrocytes show sporadic $\mathrm{Ca}^{2+}$ transients as a hallmark of astrocytic activity [220]. As demonstrated in cortical astrocytes of amyloid-depositing mice (APP/PS1), under pathological conditions, the frequency of spontaneous $\mathrm{Ca}^{2+}$ waves increases [18]. These same astrocytes exhibit higher resting $\mathrm{Ca}^{2+}$ levels. While overall astrocytic hyperactivity was noticed throughout the cortical tissue and not just in the vicinity of amyloid plaques, the astrocytes initiating the intracellular $\mathrm{Ca}^{2+}$ waves were located in plaque vicinity [18]. Further studies are needed to determine whether this was an effect of soluble $A \beta$ oligomers or $A \beta$ fibrils. $\mathrm{Ca}^{2+}$ hyperactivity in astrocytes has been associated with abnormal purinergic signaling, suggesting that reactive astrocytes release excessive amounts of ATP. This in turn activates P2Y purinoceptors mediating abnormal cytosolic $\mathrm{Ca}^{2+}$ signaling [17]. It has also been suggested that alterations in extracellular $\mathrm{Ca}^{2+}$ levels can be involved in astrocytic hyperactivity. During increased neuronal activity, extracellular $\mathrm{Ca}^{2+}$ decreases following ionotropic glutamate receptor and VGCC activation. Astrocytes sense the extracellular $\mathrm{Ca}^{2+}$ decrease and release ATP in response [221]. Increases in extracellular ATP trigger astrocytic $\mathrm{Ca}^{2+}$ transients and could contribute to AD-associated astrocytic hyperactivity.

\section{Microglial $\mathrm{Ca}^{2+}$ as a Therapeutic Target in AD}

Microglia are the major immune cells in the brain. They sense and react to alterations in brain homeostasis. They are also involved in synaptic pruning, which occurs during the first weeks of postnatal development and is critical for the maturation of neuronal networks [222]. Microglial activation is characterized by morphological alterations and production of pro- and anti-inflammatory mediators [223]. Intracellular $\mathrm{Ca}^{2+}$ regulates microglial activation from its homeostatic resting state 
to a neurotoxic-activated state. Some microglial functions, including the production and release of proinflammatory factors, such as nitric oxide $(\mathrm{NO})$ and certain cytokines, are $\mathrm{Ca}^{2+}$-dependent processes [224]. In turn, proinflammatory cytokines, tumor necrosis factor $\alpha(\mathrm{TNF} \alpha)$, interleukin $1 \beta$, and interferon $\gamma$, all increase intracellular $\mathrm{Ca}^{2+}$ levels in microglia [225-227], while anti-inflammatory cytokines decrease them [228].

$\mathrm{AD}$ has long been linked to microglial activation. Microglia surround amyloid plaques [229] after they get recruited within the first days after plaque formation [230]. Once activated, microglia internalize and break down $\mathrm{A} \beta$. Microglia activation is an early process in $\mathrm{AD}$, and it has been shown to be correlated with cognitive deficits [231]. Released proinflammatory cytokines (such as IL-1 $\beta$ and TNF- $\alpha$ ) by microglia might stimulate the release of proinflammatory substances by astrocytes, amplifying the inflammatory signal and its neurotoxicity [232,233]. Therefore, neurons and astrocytes in the vicinity of these plaques are likely subjected to high levels of proinflammatory mediators released by activated microglia. These mediators can cause alterations in the $\mathrm{Ca}^{2+}$ homeostasis of these cells [234]. Additionally, microglial cultures exposed to $A \beta$ increase their immune response (i.e., cytokine production) and intracellular $\mathrm{Ca}^{2+}$, a process that can be blocked by the dihydropyridine nifedipine and the non-dihydropyridine L-type VGCC antagonist verapamil or diltiazem [235].

Observations from in vitro data have shown that intracellular $\mathrm{Ca}^{2+}$ homeostasis is impaired in activated microglia. Microglia isolated from AD brain tissue have elevated cytosolic $\mathrm{Ca}^{2+}$ levels compared to controls and exhibit reduced responsiveness to stimuli in vitro [236]. Additionally, mouse microglia activated by lipopolysaccharide (LPS) display increased basal $\mathrm{Ca}^{2+}$ levels and a reduced agonist-induced $\mathrm{Ca}^{2+}$ signal [224]. Ramified activated microglia display large intracellular $\mathrm{Ca}^{2+}$ transients in response to the damage of individual cells in their vicinity. The use of in vivo $\mathrm{Ca}^{2+}$ imaging and multiphoton microscopy has allowed the study of microglial $\mathrm{Ca}^{2+}$ dynamics in the intact living brain. Microglia display rare $\mathrm{Ca}^{2+}$ transients in their resting state, but respond with larger $\mathrm{Ca}^{2+}$ transients when activated [237]. Microglial $\mathrm{Ca}^{2+}$ transients are attributed to $\mathrm{Ca}^{2+}$ release from intracellular stores and are prevented by the activation of ATP receptors [237]. Blocking SOCE—via knocking down or knocking out STIM1/2 and Orai-reduces immune functioning, including phagocytosis, migration, and cytokine production in primary isolated murine microglia $[238,239]$. On the other hand, blocking RyR prevents LPS-induced neurotoxicity mediated by microglia [240]. Although they have not been studied in depth, it has been suggested that microglia display $\mathrm{Ca}^{2+}$ microdomains. Some observations suggest that global $\mathrm{Ca}^{2+}$ elevations in microglia trigger phagocytosis and migration, whereas local $\mathrm{Ca}^{2+}$ increases in their processes regulate acute chemotactic migration [241]. Taken together, elevated $\mathrm{Ca}^{2+}$ levels seem to be a hallmark of activated microglia and their regulation, a potential therapeutic target for AD therapy.

Microglia express P2X receptors, a subfamily of purinergic ionotropic receptors, located in the plasma membrane which are permeable to $\mathrm{Ca}^{2+}, \mathrm{Na}^{+}$, and $\mathrm{K}^{+}$[242]. Overactivation of P2X receptors may lead to cell death via membrane depolarization, mitochondrial stress, and ROS production [243]. As measured in postmortem brain tissue from $\mathrm{AD}$ patients, $\mathrm{P} 2 \mathrm{X}_{7}$ expression is upregulated in microglia in AD [244]. This same effect was shown in plaque-associated microglia in an AD mouse model and after intrahippocampal injection of $A \beta_{42}$ [245]. It is believed that these high levels of $\mathrm{P} 2 \mathrm{X}_{7}$ contribute to the enhanced inflammatory responses observed in $\mathrm{AD}[244,246,247]$. Inhibition of $\mathrm{P}_{2} \mathrm{X}_{7}$ receptors has been shown to be neuroprotective as it reduces the dendritic spine loss induced by A $\beta$ [248], as well as $\mathrm{A} \beta$ production in general [249]. $\mathrm{P} 2 \mathrm{X}_{7} \mathrm{KO}$ mice express reduced plaque size and improved behavioral scores [250], suggesting $\mathrm{P} \mathrm{X}_{7}$ as a potential therapeutic target in AD. Additional in vitro studies have shown that $\mathrm{P} 2 \mathrm{X}_{7}$ activation leads to microglial NOD-, LRR- and pyrin domain-containing protein 3 (NLRP3) inflammasome activation, which requires $\mathrm{Ca}^{2+}$ mobilization from intracellular stores [251,252]. A $\beta$ also triggers this NLRP3 activation [253], and NLRP3 is highly activated in microglial cells surrounding amyloid plaques [253]. NLRP3 KO mice show reduced amyloid burden in the brain and have reduced memory impairment [254]. This confirms that P2 $\mathrm{X}_{7}$ and NLRP3 could be candidate targets for $\mathrm{AD}$ therapeutics. 
The triggering receptor expressed on myeloid cells 2 (TREM2) gene has been recently identified as a risk gene for $\mathrm{AD}$ [255]. Its low-frequency variants increase the risk of developing AD similar to the APOE4 allele. TREM2 is a transmembrane protein receptor expressed on microglia. It stimulates phagocytosis and suppresses inflammation [255]. TREM2 overexpression in a mouse model of AD (APP/PS1) decreased AD-related pathology and improved cognitive functions [256], suggesting that modeling microglial functions could be a protective target in AD. Immunotherapy using antibodies to stimulate TREM2 signaling in order to improve AD pathology is currently being developed by different groups. Stimulation with anti-TREM2 antibodies in vitro produced $\mathrm{Ca}^{2+}$ influx and extracellular signal-regulated kinase (ERK) signaling activation in human dendritic cells [257]. When to stimulate TREM2 to treat AD, however, is not clear, and it must be kept in mind that the use of these antibodies could alter the binding of other TREM2 ligands. Further studies will be needed to fully understand TREM2 function and its role in AD therapy.

\section{Conclusions and Future Directions}

$\mathrm{AD}$ is a multifactorial complex disease that leads to progressive dementia. Its nature brings upon the equally complex task of developing a treatment strategy. Current medications for Alzheimer's disease only treat the symptoms and cannot stop the damage that AD pathology causes to brain cells. Therefore, an urgent need exists for new target discovery that directly targets AD pathology and alters the course of its progression. On the basis of a wide range of studies, evidence suggests that treatment should be initiated in $\mathrm{AD}^{\prime}$ s earliest stages, before the start of deposition of pathology and occurrence of irreversible mental decline. $\mathrm{Ca}^{2+}$ dyshomeostasis is an early event in the AD timeline. $\mathrm{Ca}^{2+}$ dysregulation in $\mathrm{AD}$ comes as a result of hyperactivity of $\mathrm{Ca}^{2+}$ channels in the plasma membrane and intracellular compartments. It does not seem to be restricted to neurons, but rather is a global phenomenon that affects many cell types in the brain (Figure 2).

Intracellular $\mathrm{Ca}^{2+}$ homeostasis is mediated by several organelles, such as the ER, mitochondria, and lysosomes, which contribute to cell stress regulation. Increased $\mathrm{Ca}^{2+}$ concentrations in these compartments disrupt normal homeostasis, eventually leading to accumulated pathogenic proteins, which in turn further impair $\mathrm{Ca}^{2+}$ homeostasis, leading to severe alterations in neuronal circuitry. With these underlying data, it is clear that isolating potential therapeutic strategies aimed at normalizing $\mathrm{Ca}^{2+}$ levels is important. Current FDA-approved AD treatments target plasma $\mathrm{Ca}^{2+}$ channels, but more specific approaches are needed to target other prevalent and disrupted intracellular $\mathrm{Ca}^{2+}$ signaling pathways, such as those of the ER or mitochondria. As our knowledge in $\mathrm{Ca}^{2+}$ dysregulation in AD grows, it seems more obvious that targeting these other sources of $\mathrm{Ca}^{2+}$ dysregulation could be an effective therapeutic strategy.

A better understanding of the onset and progression of neurodegenerative diseases will facilitate rapid diagnosis and target selection, allowing for early treatment. A truly effective method for preventing or treating Alzheimer's disease will likely involve a combination approach for targets, such as $\mathrm{A} \beta$ plaque clearance or soluble tau removal. Additionally, reversal of cellular processes that are disrupted by $\mathrm{A} \beta$ or tau accumulation (including $\mathrm{Ca}^{2+}$ dyshomeostasis), early diagnosis, and/or lifestyle changes would also be necessary for successful therapeutic intervention. Gene therapy is an emerging therapeutic strategy for the treatment of neurodegenerative disorders, including $\mathrm{AD}$, particularly when traditional therapies are not responsive to well-validated genetic targets. Gene therapy has already shown efficacy in preclinical studies, utilizing different routes for gene delivery $[258,259]$. Recently, different groups proposed gene therapy as a strategy in the battle against $\mathrm{AD}$, as it is designed to focus on one specific target in affected brain regions. Several gene therapy strategies for AD have already been tested. These include acting directly on APP metabolism, neuroprotection, targeting inflammatory pathways, or modulating genes related to lipid metabolism [260]. Unfortunately, they have not provided an encouraging outcome so far, as they sometimes show unexpected or undesirable side effects. One of the ongoing clinical trials is designed to evaluate gene therapy use in AD patients (already clinically diagnosed) that are APOE4 homozygotes (www.clinicaltrials.gov). The study aims 
to evaluate whether intracisternal administration of APOE2 to APOE4 homozygotes AD patients will lead to conversion of the APOE protein isoforms from APOE4 homozygotes to APOE2-APOE4, which has given positive results in mice and monkeys previously [261,262]. If this therapy slows the illness in people with advanced $A D$, this could also function as a method for disease prevention, reducing the risk of disease development in healthy people. A combination of these targets and therapies should reduce stress levels and cell death in $\mathrm{AD}$, offering pathological and potentially symptomatic relief.

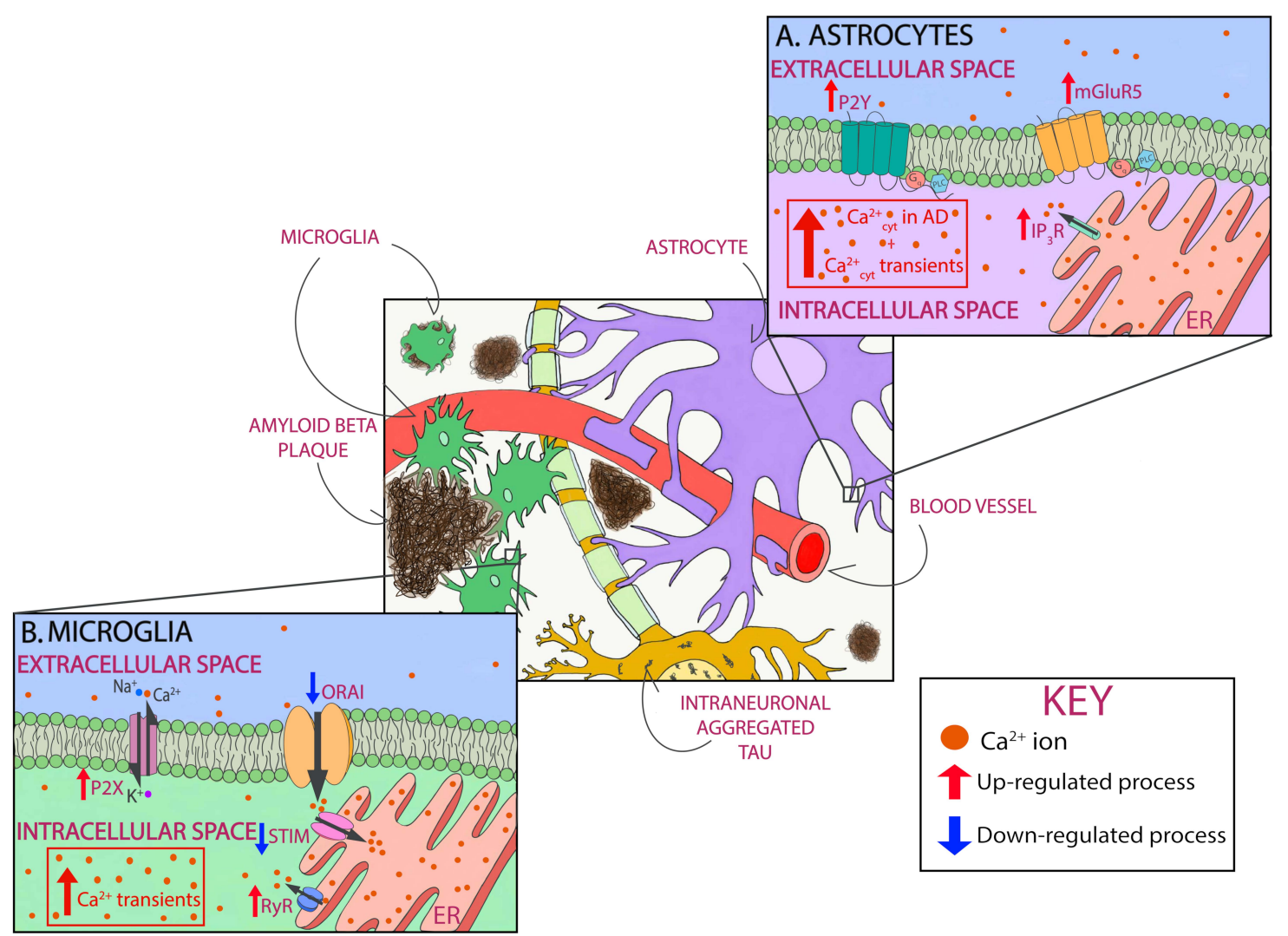

Figure 2. Astrocytic and microglial $\mathrm{Ca}^{2+}$ as a therapeutic target in AD. Schematic of glial $\mathrm{Ca}^{2+}$ cells dysregulation in the presence of AD pathology. In astrocytes, P2Y purinoceptors and glutamate metabotropic receptors mGluR5, when activated, cause $\mathrm{Ca}^{2+}$ increase by releasing $\mathrm{Ca}^{2+}$ from intracellular stores. As shown in red, all three receptors are upregulated in AD. In addition, cytosolic $\mathrm{Ca}^{2+}$ levels are increased in astrocytes, and they exhibit $\mathrm{Ca}^{2+}$ transients $(\mathbf{A})$. In microglia, $\mathrm{P} 2 \mathrm{X}$ receptors are upregulated in $\mathrm{AD}$, thus leading to $\mathrm{Ca}^{2+}$ dysregulation. SOCE, with involves STIM and Orai, is also responsible for $\mathrm{Ca}^{2+}$ influx, specifically into the lumen of the endoplasmic reticulum (ER). This pathway is downregulated in $\mathrm{AD}$ (shown in blue). RyRs mediate $\mathrm{Ca}^{2+}$ efflux from the ER, a process that is upregulated in AD. Microglia also show $\mathrm{Ca}^{2+}$ dysregulation by showing cytosolic $\mathrm{Ca}^{2+}$ transients (B).

Author Contributions: M.C.-R. and E.K.K. wrote the original draft. B.J.B. provided feedback and edited the manuscript. All authors have read and agreed to the published version of the manuscript.

Funding: This work was supported by NIHR01AG0442603, S10 RR025645, and R56AG060974 (B.J.B.), and by the Tosteson \& Fund for Medical Discovery and the BrightFocus Foundation A2019488F (M.C.-R.).

Conflicts of Interest: The authors declare no competing interests. 


\section{References}

1. Corder, E.H.; Saunders, A.M.; Strittmatter, W.J.; E Schmechel, D.; Gaskell, P.C.; Small, G.W.; Roses, A.D.; Haines, J.L.; A Pericak-Vance, M. Gene dose of apolipoprotein E type 4 allele and the risk of Alzheimer's disease in late onset families. Science 1993, 261, 921-923. [CrossRef] [PubMed]

2. A Hardy, J.; A Higgins, G.; Mayford, M.; Barzilai, A.; Keller, F.; Schacher, S.; Kandel, E. Alzheimer's disease: The amyloid cascade hypothesis. Science 1992, 256, 184-185. [CrossRef] [PubMed]

3. Davies, P. Selective Loss Of Central Cholinergic Neurons In Alzheimer's Disease. Lancet 1976, $308,1403$. [CrossRef]

4. Frost, B.; Jacks, R.L.; Diamond, M.I. Propagation of Tau Misfolding from the Outside to the Inside of a Cell. J. Biol. Chem. 2009, 284, 12845-12852. [CrossRef]

5. McGeer, P.L.; Rogers, J. Anti-inflammatory agents as a therapeutic approach to Alzheimer's disease. Neurology 1992, 42, 447. [CrossRef] [PubMed]

6. Tarasoff-Conway, J.M.; Carare, R.O.; Osorio, R.S.; Glodzik, L.; Butler, T.; Fieremans, E.; Axel, L.; Rusinek, H.; Nicholson, C.; Zlokovic, B.V.; et al. Clearance systems in the brain-Implications for Alzheimer disease. Nat. Rev. Neurol. 2015, 11, 457-470. [CrossRef] [PubMed]

7. Mattson, M.P. Calcium and neurodegeneration. Aging Cell 2007, 6, 337-350. [CrossRef]

8. Khachaturian, Z.S. Hypothesis on the Regulation of Cytosol Calcium Concentration and the Aging Brain. Neurobiol. Aging 1987, 8, 345-346. [CrossRef]

9. Boada, M.; Antúnez, C.; López-Arrieta, J.; Galán, J.J.; Morón, F.J.; Hernández, I.; Marín, J.; Martínez-Lage, P.; Alegret, M.; Carrasco, J.M.; et al. CALHM1 P86L Polymorphism is Associated with Late-Onset Alzheimer's Disease in a Recessive Model. J. Alzheimer's Dis. 2010, 20, 247-251. [CrossRef]

10. Tolar, M.; Keller, J.N.; Chan, S.; Mattson, M.P.; Marques, M.A.; Crutcher, K.A. Truncated Apolipoprotein E (ApoE) Causes Increased Intracellular Calcium and May Mediate ApoE Neurotoxicity. J. Neurosci. 1999, 19, 7100-7110. [CrossRef]

11. Zatti, G.; Ghidoni, R.; Barbiero, L.; Binetti, G.; Pozzan, T.; Fasolato, C.; Pizzo, P. The presenilin 2 M239I mutation associated with familial Alzheimer's disease reduces $\mathrm{Ca}^{2+}$ release from intracellular stores. Neurobiol. Dis. 2004, 15, 269-278. [CrossRef] [PubMed]

12. Arbel-Ornath, M.; Hudry, E.; Boivin, J.R.; Hashimoto, T.; Takeda, S.; Kuchibhotla, K.V.; Hou, S.; Lattarulo, C.R.; Belcher, A.M.; Trujillo, P.B.; et al. Soluble oligomeric amyloid-beta induces calcium dyshomeostasis that precedes synapse loss in the living mouse brain. Mol. Neurodegener. 2017, 12, 27. [CrossRef] [PubMed]

13. Busche, M.A.; Chen, X.; Henning, H.A.; Reichwald, J.; Staufenbiel, M.; Sakmann, B.; Konnerth, A. Critical role of soluble amyloid-beta for early hippocampal hyperactivity in a mouse model of Alzheimer's disease. Proc. Natl. Acad. Sci. USA 2012, 109, 8740-8745. [CrossRef] [PubMed]

14. Busche, M.A.; Eichhoff, G.; Adelsberger, H.; Abramowski, D.; Wiederhold, K.-H.; Haass, C.; Staufenbiel, M.; Konnerth, A.; Garaschuk, O. Clusters of Hyperactive Neurons Near Amyloid Plaques in a Mouse Model of Alzheimer's Disease. Science 2008, 321, 1686-1689. [CrossRef] [PubMed]

15. Kuchibhotla, K.V.; Goldman, S.T.; Lattarulo, C.R.; Wu, H.Y.; Hyman, B.T.; Bacskai, B.J. Abeta plaques lead to aberrant regulation of calcium homeostasis in vivo resulting in structural and functional disruption of neuronal networks. Neuron 2008, 59, 214-225. [CrossRef] [PubMed]

16. Busche, M.A.; Wegmann, S.; Dujardin, S.; Commins, C.; Schiantarelli, J.; Klickstein, N.; Kamath, T.V.; Carlson, G.A.; Nelken, I.; Hyman, B.T. Tau impairs neural circuits, dominating amyloid-beta effects, in Alzheimer models in vivo. Nat. Neurosci. 2019, 22, 57-64. [CrossRef]

17. Delekate, A.; Füchtemeier, M.; Schumacher, T.; Ulbrich, C.; Foddis, M.; Petzold, G.C. Metabotropic P2Y1 receptor signalling mediates astrocytic hyperactivity in vivo in an Alzheimer's disease mouse model. Nat. Commun. 2014, 5, 5422. [CrossRef]

18. Kuchibhotla, K.V.; Lattarulo, C.R.; Hyman, B.T.; Bacskai, B.J. Synchronous Hyperactivity and Intercellular Calcium Waves in Astrocytes in Alzheimer Mice. Science 2009, 323, 1211-1215. [CrossRef]

19. Wang, X.; Kastanenka, K.V.; Arbel-Ornath, M.; Commins, C.; Kuzuya, A.; Lariviere, A.J.; Krafft, G.A.; Hefti, F.; Jerecic, J.; Bacskai, B.J. An acute functional screen identifies an effective antibody targeting amyloid-beta oligomers based on calcium imaging. Sci. Rep. 2018, 8, 4634. [CrossRef]

20. Palop, J.J.; Mucke, L. Network abnormalities and interneuron dysfunction in Alzheimer disease. Nat. Rev. Neurosci. 2016, 17, 777-792. [CrossRef] 
21. Khachaturian, Z.S. The role of calcium regulation in brain aging: Reexamination of a hypothesis. Aging Clin. Exp. Res. 1989, 1, 17-34. [CrossRef] [PubMed]

22. LaFerla, F.M. Calcium dyshomeostasis and intracellular signalling in alzheimer's disease. Nat. Rev. Neurosci. 2002, 3, 862-872. [CrossRef] [PubMed]

23. Abeysinghe, A.; Deshapriya, R.; Udawatte, C. Alzheimer's disease; a review of the pathophysiological basis and therapeutic interventions. Life Sci. 2020, 256, 117996. [CrossRef] [PubMed]

24. Panza, F.; Solfrizzi, V.; Imbimbo, B.P.; Logroscino, G. Amyloid-directed monoclonal antibodies for the treatment of Alzheimer's disease: The point of no return? Expert Opin. Biol. Ther. 2014, 14, 1465-1476. [CrossRef]

25. Sevigny, J.; Chiao, P.; Bussiere, T.; Weinreb, P.H.; Williams, L.; Maier, M.; Dunstan, R.; Salloway, S.; Chen, T.; Ling, Y.; et al. The antibody aducanumab reduces Abeta plaques in Alzheimer's disease. Nature 2016, 537, 50-56. [CrossRef]

26. Selkoe, D.J.; Hardy, J. The amyloid hypothesis of Alzheimer's disease at 25 years. EMBO Mol. Med. 2016, 8, 595-608. [CrossRef]

27. Bagur, R.; Hajnóczky, G. Intracellular $\mathrm{Ca}^{2+}$ Sensing: Its Role in Calcium Homeostasis and Signaling. Mol. Cell 2017, 66, 780-788. [CrossRef]

28. Berridge, M.J.; Lipp, P.; Bootman, M.D. The versatility and universality of calcium signalling. Nat. Rev. Mol. Cell Biol. 2000, 1, 11-21. [CrossRef]

29. Mattson, M.P. Calcium and neuronal injury in Alzheimer's disease. Contributions of beta-amyloid precursor protein mismetabolism, free radicals, and metabolic compromise. Ann. N. Y. Acad. Sci. 1994, 747, 50-76. [CrossRef]

30. Arispe, N.; Rojas, E.; Pollard, H.B. Alzheimer disease amyloid beta protein forms calcium channels in bilayer membranes: Blockade by tromethamine and aluminum. Proc. Natl. Acad. Sci. USA 1993, 90,567-571. [CrossRef]

31. De Felice, F.G.; Velasco, P.T.; Lambert, M.P.; Viola, K.; Fernandez, S.J.; Ferreira, S.T.; Klein, W.L. Abeta oligomers induce neuronal oxidative stress through an N-methyl-D-aspartate receptor-dependent mechanism that is blocked by the Alzheimer drug memantine. J. Biol. Chem. 2007, 282, 11590-11601. [CrossRef] [PubMed]

32. Pourbadie, H.G.; Naderi, N.; Mehranfard, N.; Janahmadi, M.; Khodagholi, F.; Motamedi, F. Preventing Effect of L-Type Calcium Channel Blockade on Electrophysiological Alterations in Dentate Gyrus Granule Cells Induced by Entorhinal Amyloid Pathology. PLoS ONE 2015, 10, e0117555. [CrossRef] [PubMed]

33. Stutzmann, G.E.; Smith, I.; Caccamo, A.; Oddo, S.; LaFerla, F.M.; Parker, I. Enhanced Ryanodine Receptor Recruitment Contributes to $\mathrm{Ca}^{2+}$ Disruptions in Young, Adult, and Aged Alzheimer's Disease Mice. J. Neurosci. 2006, 26, 5180-5189. [CrossRef] [PubMed]

34. Lawlor, B.A.; Kennelly, S.; O’Dwyer, S.; Cregg, F.; Walsh, C.D.; Cohen, R.; Kenny, R.A.; Howard, R.; Murphy, C.; Adams, J.; et al. NILVAD protocol: A European multicentre double-blind placebo-controlled trial of nilvadipine in mild-to-moderate Alzheimer's disease. BMJ Open 2014, 4, e006364. [CrossRef] [PubMed]

35. Lawlor, B.A.; Segurado, R.; Kennelly, S.; Rikkert, M.G.M.O.; Howard, R.; Pasquier, F.; Börjesson-Hanson, A.; Tsolaki, M.; Lucca, U.; Molloy, D.W.; et al. Nilvadipine in mild to moderate Alzheimer disease: A randomised controlled trial. PLoS Med. 2018, 15, e1002660. [CrossRef] [PubMed]

36. Esteras, N.; Kundel, F.; Amodeo, G.F.; Pavlov, E.V.; Klenerman, D.; Abramov, A.Y. Insoluble tau aggregates induce neuronal death through modification of membrane ion conductance, activation of voltage-gated calcium channels and NADPH oxidase. FEBS J. 2020. [CrossRef] [PubMed]

37. Dreses-Werringloer, U. A polymorphism in CALHM1 influences $\mathrm{Ca}^{2+}$ homeostasis, Abeta levels, and Alzheimer's disease risk. Cell 2008, 133, 1149-1161. [CrossRef] [PubMed]

38. Minster, R.L.; Demirci, F.Y.; DeKosky, S.T.; Kamboh, M.I. No association betweenCALHM1variation and risk of Alzheimer disease. Hum. Mutat. 2009, 30, E566-E569. [CrossRef]

39. Tan, E.; Ho, P.; Cheng, S.; Yih, Y.; Li, H.; Fook-Chong, S.; Lee, W.; Zhao, Y. CALHM1 variant is not associated with Alzheimer's disease among Asians. Neurobiol. Aging 2011, 32, 546.e11-546.e12. [CrossRef]

40. Vingtdeux, V.; Chang, E.H.; Frattini, S.A.; Zhao, H.; Chandakkar, P.; Adrien, L.; Strohl, J.J.; Gibson, E.L.; Ohmoto, M.; Matsumoto, I.; et al. CALHM1 deficiency impairs cerebral neuron activity and memory flexibility in mice. Sci. Rep. 2016, 6, 24250. [CrossRef]

41. Liu, J.; Chang, L.; Song, Y.; Li, H.; Wu, Y. The Role of NMDA Receptors in Alzheimer's Disease. Front. Neurosci. 2019, 13, 43. [CrossRef] [PubMed] 
42. Hardingham, G.E.; Bading, H. Synaptic versus extrasynaptic NMDA receptor signalling: Implications for neurodegenerative disorders. Nat. Rev. Neurosci. 2010, 11, 682-696. [CrossRef] [PubMed]

43. Ferreira, I.; Bajouco, L.; Mota, S.; Auberson, Y.; Oliveira, C.; Rego, A.C. Amyloid beta peptide 1-42 disturbs intracellular calcium homeostasis through activation of GluN2B-containing N-methyl-d-aspartate receptors in cortical cultures. Cell Calcium 2012, 51, 95-106. [CrossRef] [PubMed]

44. Ronicke, R.; Mikhaylova, M.; Ronicke, S.; Meinhardt, J.; Schroder, U.H.; Fandrich, M.; Reiser, G.; Kreutz, M.R.; Reymann, K.G. Early neuronal dysfunction by amyloid beta oligomers depends on activation of NR2B-containing NMDA receptors. Neurobiol. Aging 2011, 32, 2219-2228. [CrossRef]

45. Zhang, Y.; Li, P.; Feng, J.; Wu, M. Dysfunction of NMDA receptors in Alzheimer's disease. Neurol. Sci. 2016, 37, 1039-1047. [CrossRef]

46. Roberson, E.D.; Scearce-Levie, K.; Palop, J.J.; Yan, F.; Cheng, I.H.; Wu, T.; Gerstein, H.; Yu, G.Q.; Mucke, L. Reducing endogenous tau ameliorates amyloid beta-induced deficits in an Alzheimer's disease mouse model. Science 2007, 316, 750-754. [CrossRef]

47. Decker, J.M.; Krüger, L.; Sydow, A.; Dennissen, F.J.; Siskova, Z.; Mandelkow, E.; Mandelkow, E. The Tau/A152T mutation, a risk factor for frontotemporal-spectrum disorders, leads to NR 2B receptor-mediated excitotoxicity. EMBO Rep. 2016, 17, 552-569. [CrossRef]

48. Maeda, S.; Djukic, B.; Taneja, P.; Yu, G.; Lo, I.; Davis, A.; Craft, R.; Guo, W.; Wang, X.; Kim, D.; et al. Expression of A152T human tau causes age-dependent neuronal dysfunction and loss in transgenic mice. EMBO Rep. 2016, 17, 530-551. [CrossRef]

49. Esclaire, F.; Lesort, M.; Blanchard, C.; Hugon, J. Glutamate toxicity enhances tau gene expression in neuronal cultures. J. Neurosci. Res. 1997, 49, 309-318. [CrossRef]

50. Sindou, P.; Lesort, M.; Couratier, P.; Yardin, C.; Esclaire, F.; Hugon, J. Glutamate increases tau phosphorylation in primary neuronal cultures from fetal rat cerebral cortex. Brain Res. 1994, 646, 124-128. [CrossRef]

51. Sun, X.-Y.; Tuo, Q.-Z.; Liuyang, Z.-Y.; Xie, A.-J.; Feng, X.-L.; Yan, X.; Qiu, M.; Li, S.; Wang, X.-L.; Cao, F.-Y.; et al. Extrasynaptic NMDA receptor-induced tau overexpression mediates neuronal death through suppressing survival signaling ERK phosphorylation. Cell Death Dis. 2016, 7, e2449. [CrossRef] [PubMed]

52. Lipton, S.A. Failures and successes of NMDA receptor antagonists: Molecular basis for the use of open-channel blockers like memantine in the treatment of acute and chronic neurologic insults. NeuroRx 2004, 1, 101-110. [CrossRef] [PubMed]

53. Kishi, T.; Matsunaga, S.; Oya, K.; Nomura, I.; Ikuta, T.; Iwata, N. Memantine for Alzheimer's Disease: An Updated Systematic Review and Meta-analysis. J. Alzheimer's Dis. 2017, 60, 401-425. [CrossRef] [PubMed]

54. Figueiredo, C.P.; Clarke, J.R.; Ledo, J.H.; Ribeiro, F.C.; Costa, C.V.; Melo, H.M.; Mota-Sales, A.P.; Saraiva, L.M.; Klein, W.L.; Sebollela, A. et al.; et al. Memantine rescues transient cognitive impairment caused by high-molecular-weight abeta oligomers but not the persistent impairment induced by low-molecular-weight oligomers. J. Neurosci. 2013, 33, 9626-9634. [CrossRef]

55. Song, M.S.; Rauw, G.; Baker, G.B.; Kar, S. Memantine protects rat cortical cultured neurons against $\beta$-amyloid-induced toxicity by attenuating tau phosphorylation. Eur. J. Neurosci. 2008, 28, 1989-2002. [CrossRef]

56. Wevers, A.; Monteggia, L.; Nowacki, S.; Bloch, W.; Schutz, U.; Lindstrom, J.; Pereira, E.F.R.; Eisenberg, H.; Giacobini, E.; De Vos, R.A.I.; et al. Expression of nicotinic acetylcholine receptor subunits in the cerebral cortex in Alzheimer's disease: Histotopographical correlation with amyloid plaques and hyperphosphorylated-tau protein. Eur. J. Neurosci. 1999, 11, 2551-2565. [CrossRef]

57. Ferreira-Vieira, T.H.; Guimaraes, I.M.; Silva, F.R.; Ribeiro, F.M. Alzheimer's disease: Targeting the Cholinergic System. Curr. Neuropharmacol. 2016, 14, 101-115. [CrossRef]

58. Lahiri, D.K.; Rogers, J.T.; Greig, N.H.; Sambamurti, K. Rationale for the Development of Cholinesterase Inhibitors as Anti- Alzheimer Agents. Curr. Pharm. Des. 2004, 10, 3111-3119. [CrossRef]

59. Herholz, K. Acetylcholine esterase activity in mild cognitive impairment and Alzheimer's disease. Eur. J. Nucl. Med. Mol. Imaging 2008, 35, 25-29. [CrossRef]

60. Patel, L.; Grossberg, G.T. Combination Therapy for Alzheimer's Disease. Drugs Aging 2011, 28, 539-546. [CrossRef]

61. Gómez-Ramos, A.; Díaz-Hernández, M.; Rubio, A.; Miras-Portugal, M.T.; Avila, J. Extracellular tau promotes intracellular calcium increase through M1 and M3 muscarinic receptors in neuronal cells. Mol. Cell. Neurosci. 2008, 37, 673-681. [CrossRef] [PubMed] 
62. Hartigan, J.A.; Johnson, G.V.W. Transient Increases in Intracellular Calcium Result in Prolonged Site-selective Increases in Tau Phosphorylation through a Glycogen Synthase Kinase 3 $\beta$-dependent Pathway. J. Biol. Chem. 1999, 274, 21395-21401. [CrossRef] [PubMed]

63. Giacobini, E.; Gold, G. Alzheimer disease therapy-Moving from amyloid-beta to tau. Nat. Rev. Neurol. 2013, 9, 677-686. [CrossRef]

64. Kang, S.; Son, S.M.; Baik, S.H.; Yang, J.; Mook-Jung, I. Autophagy-Mediated Secretory Pathway is Responsible for Both Normal and Pathological Tau in Neurons. J. Alzheimer's Dis. 2019, 70, 667-680. [CrossRef] [PubMed]

65. Clavaguera, F.; Bolmont, T.; Crowther, R.A.; Abramowski, D.; Frank, S.; Probst, A.; Fraser, G.; Stalder, A.K.; Beibel, M.; Staufenbiel, M.; et al. Transmission and spreading of tauopathy in transgenic mouse brain. Nat. Cell Biol. 2009, 11, 909-913. [CrossRef] [PubMed]

66. Devos, S.L.; Corjuc, B.T.; Oakley, D.H.; Nobuhara, C.K.; Bannon, R.N.; Chase, A.; Commins, C.; Gonzalez, J.A.; Dooley, P.M.; Frosch, M.P.; et al. Synaptic Tau Seeding Precedes Tau Pathology in Human Alzheimer's Disease Brain. Front. Neurosci. 2018, 12, 267. [CrossRef]

67. Friedhoff, P.; Von Bergen, M.; Mandelkow, E.-M.; Davies, P. A nucleated assembly mechanism of Alzheimer paired helical filaments. Proc. Nat. Acad. Sci. USA 1998, 95, 15712-15717. [CrossRef]

68. Colin, M.; Dujardin, S.; Schraen-Maschke, S.; Meno-Tetang, G.; Duyckaerts, C.; Courade, J.-P.; Buée, L. From the prion-like propagation hypothesis to therapeutic strategies of anti-tau immunotherapy. Acta Neuropathol. 2020, 139, 3-25. [CrossRef]

69. Congdon, E.E.; Sigurdsson, E.M. Tau-targeting therapies for Alzheimer disease. Nat. Rev. Neurol. 2018, 14, 399-415. [CrossRef]

70. Jadhav, S.; Avila, J.; Schöll, M.; Kovacs, G.G.; Kövari, E.; Skrabana, R.; Evans, L.D.; Kontsekova, E.; Malawska, B.; De Silva, R.; et al. A walk through tau therapeutic strategies. Acta Neuropathol. Commun. 2019, 7, 1-31. [CrossRef]

71. Cummings, J.; Lee, G.; Ritter, A.; Sabbagh, M.; Zhong, K. Alzheimer's disease drug development pipeline. Alzheimer's Dement. Transl. Res. Clin. Interv. 2019, 5, 272-293. [CrossRef]

72. Cirrito, J.R.; Yamada, K.A.; Finn, M.B.; Sloviter, R.S.; Bales, K.R.; May, P.C.; Schoepp, D.D.; Paul, S.M.; Mennerick, S.; Holtzman, D.M. Synaptic activity regulates interstitial fluid amyloid-beta levels in vivo. Neuron 2005, 48, 913-922. [CrossRef] [PubMed]

73. Kamenetz, F.; Tomita, T.; Hsieh, H.; Seabrook, G.; Borchelt, D.; Iwatsubo, T.; Sisodia, S.; Malinow, R. APP Processing and Synaptic Function. Neuron 2003, 37, 925-937. [CrossRef]

74. Palop, J.J. Epilepsy and Cognitive Impairments in Alzheimer Disease. Arch. Neurol. 2009, 66, 435-440. [CrossRef] [PubMed]

75. Sanchez, P.E.; Zhu, L.; Verret, L.; Vossel, K.A.; Orr, A.G.; Cirrito, J.R.; Devidze, N.; Ho, K.; Yu, G.-Q.; Palop, J.J.; et al. Levetiracetam suppresses neuronal network dysfunction and reverses synaptic and cognitive deficits in an Alzheimer's disease model. Proc. Nat. Acad. Sci. USA 2012, 109, E2895-E2903. [CrossRef]

76. Kastanenka, K.V.; Bussiere, T.; Shakerdge, N.; Qian, F.; Weinreb, P.H.; Rhodes, K.; Bacskai, B.J. Immunotherapy with Aducanumab Restores Calcium Homeostasis in Tg2576 Mice. J. Neurosci. 2016, 36, 12549-12558. [CrossRef]

77. Schneider, L. A resurrection of aducanumab for Alzheimer's disease. Lancet Neurol. 2020, 19, 111-112. [CrossRef]

78. Mekahli, D.; Bultynck, G.; Parys, J.B.; De Smedt, H.; Missiaen, L. Endoplasmic-Reticulum Calcium Depletion and Disease. Cold Spring Harb. Perspect. Biol. 2011, 3, a004317. [CrossRef]

79. Ito, E.; Oka, K.; Etcheberrigaray, R.; Nelson, T.J.; McPHIE, D.L.; Tofel-Grehl, B.; Gibson, G.E.; Alkon, D.L. Internal $\mathrm{Ca}^{2+}$ mobilization is altered in fibroblasts from patients with Alzheimer disease. Proc. Nat. Acad. Sci. USA 1994, 91, 534-538. [CrossRef]

80. Etcheberrigaray, R.; Hirashima, N.; Nee, L.; Prince, J.; Govoni, S.; Racchi, M.; Tanzi, R.E.; Alkon, D.L. Calcium responses in fibroblasts from asymptomatic members of Alzheimer's disease families. Neurobiol. Dis. 1998, 5, 37-45. [CrossRef]

81. Stutzmann, G.E.; Caccamo, A.; LaFerla, F.M.; Parker, I. Dysregulated IP3 Signaling in Cortical Neurons of Knock-In Mice Expressing an Alzheimer's-Linked Mutation in Presenilin1 Results in Exaggerated $\mathrm{Ca}^{2+}$ Signals and Altered Membrane Excitability. J. Neurosci. 2004, 24, 508-513. [CrossRef] [PubMed] 
82. Shilling, D.; Müller, M.; Takano, H.; Mak, D.-O.D.; Abel, T.; Coulter, D.A.; Foskett, J.K. Suppression of InsP3 Receptor-Mediated $\mathrm{Ca}^{2+}$ Signaling Alleviates Mutant Presenilin-Linked Familial Alzheimer's Disease Pathogenesis. J. Neurosci. 2014, 34, 6910-6923. [CrossRef]

83. De Strooper, B.; Annaert, W.; Cupers, P.; Saftig, P.; Craessaerts, K.; Mumm, J.S.; Schroeter, E.H.; Schrijvers, V.; Wolfe, M.S.; Ray, W.J.; et al. A presenilin-1-dependent gamma-secretase-like protease mediates release of Notch intracellular domain. Nature 1999, 398, 518-522. [CrossRef]

84. Struhl, G.; Greenwald, I. Presenilin is required for activity and nuclear access of Notch in Drosophila. Nat. Cell Biol. 1999, 398, 522-525. [CrossRef]

85. A Saura, C.; Choi, S.-Y.; Beglopoulos, V.; Malkani, S.; Zhang, D.; Rao, B.S.S.; Chattarji, S.; Kelleher, R.J.; Kandel, E.R.; Duff, K.; et al. Loss of Presenilin Function Causes Impairments of Memory and Synaptic Plasticity Followed by Age-Dependent Neurodegeneration. Neuron 2004, 42, 23-36. [CrossRef]

86. Watanabe, H.; Xia, D.; Kanekiyo, T.; Kelleher, R.J.; Shen, J. Familial Frontotemporal Dementia-Associated Presenilin-1 c.548G > T Mutation Causes Decreased mRNA Expression and Reduced Presenilin Function in Knock-In Mice. J. Neurosci. 2012, 32, 5085-5096. [CrossRef] [PubMed]

87. Xia, W.; Zhang, J.; Kholodenko, D.; Citron, M.; Podlisny, M.B.; Teplow, D.B.; Haass, C.; Seubert, P.; Koo, E.H.; Selkoe, D.J. Enhanced Production and Oligomerization of the 42-residue Amyloid $\beta$-Protein by Chinese Hamster Ovary Cells Stably Expressing Mutant Presenilins. J. Biol. Chem. 1997, 272, 7977-7982. [CrossRef] [PubMed]

88. Duff, K.; Eckman, C.; Zehr, C.; Yu, X.; Prada, C.M.; Perez-tur, J.; Hutton, M.; Buee, L.; Harigaya, Y.; Yager, D.; et al. Increased amyloid-beta42(43) in brains of mice expressing mutant presenilin. Nature 1996, 383, 710-713. [CrossRef]

89. Scheuner, D.; Eckman, C.; Jensen, M.; Song, X.; Citron, M.; Suzuki, N.; Bird, T.D.; Hardy, J.; Hutton, M.; Kukull, W.; et al. Secreted amyloid beta-protein similar to that in the senile plaques of Alzheimer's disease is increased in vivo by the presenilin 1 and 2 and APP mutations linked to familial Alzheimer's disease. Nat. Med. 1996, 2, 864-870. [CrossRef]

90. Borchelt, D.R.; Thinakaran, G.; Eckman, C.B.; Lee, M.K.; Davenport, F.; Ratovitsky, T.; Prada, C.M.; Kim, G.; Seekins, S.; Yager, D.; et al. Familial Alzheimer's disease-linked presenilin 1 variants elevate Abeta1-42/1-40 ratio in vitro and in vivo. Neuron 1996, 17, 1005-1013. [CrossRef]

91. Shen, J.; Iii, R.J.K. The presenilin hypothesis of Alzheimer's disease: Evidence for a loss-of-function pathogenic mechanism. Proc. Nat. Acad. Sci. USA 2007, 104, 403-409. [CrossRef] [PubMed]

92. Tu, H.; Nelson, O.; Bezprozvanny, A.; Wang, Z.; Lee, S.-F.; Hao, Y.-H.; Serneels, L.; De Strooper, B.; Yu, G.; Bezprozvanny, I. Presenilins Form ER Ca ${ }^{2+}$ Leak Channels, a Function Disrupted by Familial Alzheimer's Disease-Linked Mutations. Cell 2006, 126, 981-993. [CrossRef] [PubMed]

93. McCombs, J.E.; Gibson, E.A.; Palmer, A.E. Using a genetically targeted sensor to investigate the role of presenilin-1 in ER Ca ${ }^{2+}$ levels and dynamics. Mol. Biosyst. 2010, 6, 1640-1649. [CrossRef] [PubMed]

94. Shilling, D.; Mak, D.-O.D.; Kang, D.E.; Foskett, J.K. Lack of Evidence for Presenilins as Endoplasmic Reticulum Ca ${ }^{2+}$ Leak Channels. J. Biol. Chem. 2012, 287, 10933-10944. [CrossRef]

95. Wang, Q.C.; Zheng, Q.; Tan, H.; Zhang, B.; Li, X.; Yang, Y.; Yu, J.; Liu, Y.; Chai, H.; Wang, X.; et al. TMCO1 Is an ER Ca ${ }^{2+}$ Load-Activated $\mathrm{Ca}^{2+}$ Channel. Cell 2016, 165, 1454-1466. [CrossRef]

96. Bruno, A.M.; Huang, J.Y.; Bennett, D.A.; Marr, R.A.; Hastings, M.L.; Stutzmann, G.E. Altered ryanodine receptor expression in mild cognitive impairment and Alzheimer's disease. Neurobiol. Aging 2012, 33, 1001.e1-1001.e6. [CrossRef]

97. Chan, S.L.; Mayne, M.; Holden, C.P.; Geiger, J.D.; Mattson, M.P. Presenilin-1 Mutations Increase Levels of Ryanodine Receptors and Calcium Release in PC12 Cells and Cortical Neurons. J. Biol. Chem. 2000, 275, 18195-18200. [CrossRef]

98. Briggs, C.A.; Chakroborty, S.; Stutzmann, G.E. Emerging pathways driving early synaptic pathology in Alzheimer's disease. Biochem. Biophys. Res. Commun. 2017, 483, 988-997. [CrossRef]

99. Rybalchenko, V.; Hwang, S.-Y.; Rybalchenko, N.; Koulen, P. The cytosolic N-terminus of presenilin-1 potentiates mouse ryanodine receptor single channel activity. Int. J. Biochem. Cell Biol. 2008, 40, 84-97. [CrossRef]

100. Wu, B.; Yamaguchi, H.; Lai, F.A.; Shen, J. Presenilins regulate calcium homeostasis and presynaptic function via ryanodine receptors in hippocampal neurons. Proc. Nat. Acad. Sci. USA 2013, 110, 15091-15096. [CrossRef] 
101. Oulès, B.; Del Prete, D.; Greco, B.; Zhang, X.; Lauritzen, I.; Sevalle, J.; Moreno, S.; Paterlini-Bréchot, P.; Trebak, M.; Checler, F.; et al. Ryanodine receptor blockade reduces amyloid-beta load and memory impairments in Tg2576 mouse model of Alzheimer disease. J. Neurosci. 2012, 32, 11820-11834. [CrossRef] [PubMed]

102. Zahradník, I.; Györke, S.; Zahradníková, A. Calcium Activation of Ryanodine Receptor Channels-Reconciling RyR Gating Models with Tetrameric Channel Structure. J. Gen. Physiol. 2005, 126, 515-527. [CrossRef] [PubMed]

103. Ferreiro, E.; Oliveira, C.R.; Pereira, C. Involvement of endoplasmic reticulum $\mathrm{Ca}^{2+}$ release through ryanodine and inositol 1,4,5-triphosphate receptors in the neurotoxic effects induced by the amyloid-beta peptide. J. Neurosci. Res. 2004, 76, 872-880. [CrossRef] [PubMed]

104. Supnet, C.; Grant, J.; Kong, H.; Westaway, D.; Mayne, M. Amyloid- $\beta$-(1-42) Increases Ryanodine Receptor-3 Expression and Function in Neurons of TgCRND8 Mice. J. Biol. Chem. 2006, 281, 38440-38447. [CrossRef]

105. Bussiere, R.; Lacampagne, A.; Reiken, S.; Liu, X.; Scheuerman, V.; Zalk, R.; Martin, C.; Checler, F.; Marks, A.R.; Chami, M. Amyloid beta production is regulated by beta2-adrenergic signaling-mediated post-translational modifications of the ryanodine receptor. J. Biol. Chem. 2017, 292, 10153-10168. [CrossRef]

106. Lacampagne, A.; Liu, X.; Reiken, S.; Bussiere, R.; Meli, A.C.; Lauritzen, I.; Teich, A.F.; Zalk, R.; Saint, N.; Arancio, O.; et al. Post-translational remodeling of ryanodine receptor induces calcium leak leading to Alzheimer's disease-like pathologies and cognitive deficits. Acta Neuropathol. 2017, 134, 749-767. [CrossRef]

107. Brunello, L.; Zampese, E.; Florean, C.; Pozzan, T.; Pizzo, P.; Fasolato, C. Presenilin-2 dampens intracellular $\mathrm{Ca}^{2+}$ stores by increasing $\mathrm{Ca}^{2+}$ leakage and reducing $\mathrm{Ca}^{2+}$ uptake. J. Cell. Mol. Med. 2009, 13, 3358-3369. [CrossRef]

108. Green, K.N.; Demuro, A.; Akbari, Y.; Hitt, B.D.; Smith, I.F.; Parker, I.; LaFerla, F.M. SERCA pump activity is physiologically regulated by presenilin and regulates amyloid beta production. J. Cell Biol. 2008, 181, 1107-1116. [CrossRef]

109. Peng, J.; Liang, G.; Inan, S.; Wu, Z.; Joseph, D.J.; Meng, Q.; Peng, Y.; Eckenhoff, M.F.; Wei, H. Dantrolene ameliorates cognitive decline and neuropathology in Alzheimer triple transgenic mice. Neurosci. Lett. 2012, 516, 274-279. [CrossRef]

110. Wu, Z.; Yang, B.; Liu, C.; Liang, G.; Liu, W.; Pickup, S.; Meng, Q.; Tian, Y.; Li, S.; Eckenhoff, M.F.; et al. Long-term Dantrolene Treatment Reduced Intraneuronal Amyloid in Aged Alzheimer Triple Transgenic Mice. Alzheimer Dis. Assoc. Disord. 2015, 29, 184-191. [CrossRef]

111. Bollimuntha, S.; Pani, B.; Singh, B.B. Neurological and Motor Disorders: Neuronal Store-Operated Ca ${ }^{2+}$ Signaling: An Overview and Its Function. Atherosclerosis 2017, 993, 535-556. [CrossRef]

112. Kraft, R. STIM and ORAI proteins in the nervous system. Channels 2015, 9, 245-252. [CrossRef] [PubMed]

113. Putney, J.W. The Physiological Function of Store-operated Calcium Entry. Neurochem. Res. 2011, 36, 1157-1165. [CrossRef] [PubMed]

114. Leissring, M.A.; Akbari, Y.; Fanger, C.M.; Cahalan, M.D.; Mattson, M.P.; LaFerla, F.M. Capacitative Calcium Entry Deficits and Elevated Luminal Calcium Content in Mutant Presenilin-1 Knockin Mice. J. Cell Biol. 2000, 149, 793-798. [CrossRef]

115. Smith, I.; Boyle, J.; Vaughan, P.; Pearson, H.; Cowburn, R.; Peers, C. Ca ${ }^{2+}$ Stores and capacitative $\mathrm{Ca}^{2+}$ entry $^{2}$ in human neuroblastoma (SH-SY5Y) cells expressing a familial Alzheimer's disease presenilin-1 mutation. Brain Res. 2002, 949, 105-111. [CrossRef]

116. Calvo-Rodriguez, M.; Hernando-Perez, E.; Nunez, L.; Villalobos, C. Amyloid beta Oligomers Increase ER-Mitochondria $\mathrm{Ca}^{2+}$ Cross Talk in Young Hippocampal Neurons and Exacerbate Aging-Induced Intracellular $\mathrm{Ca}^{2+}$ Remodeling. Front. Cell. Neurosci. 2019, 13, 22. [CrossRef] [PubMed]

117. Sun, S.; Zhang, H.; Liu, J.; Popugaeva, E.; Xu, N.-J.; Feske, S.; White, C.L.; Bezprozvanny, I. Reduced Synaptic STIM2 Expression and Impaired Store-Operated Calcium Entry Cause Destabilization of Mature Spines in Mutant Presenilin Mice. Neuron 2014, 82, 79-93. [CrossRef]

118. Yoo, A.S.; Cheng, I.; Chung, S.; Grenfell, T.Z.; Lee, H.; Pack-Chung, E.; Handler, M.; Shen, J.; Xia, W.; Tesco, G.; et al. Presenilin-Mediated Modulation of Capacitative Calcium Entry. Neuron 2000, 27, 561-572. [CrossRef]

119. Zhang, H.; Wu, L.; Pchitskaya, E.; Zakharova, O.D.; Saito, T.; Saido, T.C.; Bezprozvanny, I.B. Neuronal Store-Operated Calcium Entry and Mushroom Spine Loss in Amyloid Precursor Protein Knock-In Mouse Model of Alzheimer's Disease. J. Neurosci. 2015, 35, 13275-13286. [CrossRef] 
120. Tsukamoto, A.; Kaneko, Y. Thapsigargin, a $\mathrm{Ca}^{2+}$-ATPase inhibitor, depletes the intracellular $\mathrm{Ca}^{2+}$ pool and induces apoptosis in human hepatoma cells. Cell Biol. Int. 1993, 17, 969-970. [CrossRef]

121. Soboloff, J.; Berger, S.A. Sustained ER Ca ${ }^{2+}$ Depletion Suppresses Protein Synthesis and Induces Activation-enhanced Cell Death in Mast Cells. J. Biol. Chem. 2002, 277, 13812-13820. [CrossRef] [PubMed]

122. Popugaeva, E.; Pchitskaya, E.; Speshilova, A.B.; Alexandrov, S.; Zhang, H.; Vlasova, O.; Bezprozvanny, I.B. STIM2 protects hippocampal mushroom spines from amyloid synaptotoxicity. Mol. Neurodegener. 2015, 10, 37. [CrossRef] [PubMed]

123. Li, M.; Liu, E.; Zhou, Q.; Li, S.; Wang, X.; Liu, Y.; Wang, L.; Sun, D.; Ye, J.; Gao, Y.; et al. TRPC1 Null Exacerbates Memory Deficit and Apoptosis Induced by Amyloid-beta. J. Alzheimer's Dis. JAD 2018, 63, 761-772. [CrossRef] [PubMed]

124. Mishra, P.; Chan, D.C. Metabolic regulation of mitochondrial dynamics. J. Cell Biol. 2016, 212, 379-387. [CrossRef]

125. Werth, J.L.; A Thayer, S. Mitochondria buffer physiological calcium loads in cultured rat dorsal root ganglion neurons. J. Neurosci. 1994, 14, 348-356. [CrossRef]

126. Billups, B.; Forsythe, I.D. Presynaptic Mitochondrial Calcium Sequestration Influences Transmission at Mammalian Central Synapses. J. Neurosci. 2002, 22, 5840-5847. [CrossRef]

127. Wescott, A.P.; Kao, J.P.Y.; Lederer, W.J.; Boyman, L. Voltage-energized calcium-sensitive ATP production by mitochondria. Nat. Metab. 2019, 1, 975-984. [CrossRef] [PubMed]

128. Baughman, J.M.; Perocchi, F.; Girgis, H.S.; Plovanich, M.; Belcher-Timme, C.A.; Sancak, Y.; Bao, X.R.; Strittmatter, L.; A Goldberger, O.; Bogorad, R.L.; et al. Integrative genomics identifies MCU as an essential component of the mitochondrial calcium uniporter. Nat. Cell Biol. 2011, 476, 341-345. [CrossRef] [PubMed]

129. De Stefani, D.; Raffaello, A.; Teardo, E.; Szabò, I.; Rizzuto, R. A forty-kilodalton protein of the inner membrane is the mitochondrial calcium uniporter. Nat. Cell Biol. 2011, 476, 336-340. [CrossRef] [PubMed]

130. Raffaello, A.; De Stefani, D.; Sabbadin, D.; Teardo, E.; Merli, G.; Picard, A.; Checchetto, V.; Moro, S.; Szabò, I.; Rizzuto, R. The mitochondrial calcium uniporter is a multimer that can include a dominant-negative pore-forming subunit. EMBO J. 2013, 32, 2362-2376. [CrossRef] [PubMed]

131. Lambert, J.P.; Luongo, T.S.; Tomar, D.; Jadiya, P.; Gao, E.; Zhang, X.; Lucchese, A.M.; Kolmetzky, D.W.; Shah, N.S.; Elrod, J.W. MCUB Regulates the Molecular Composition of the Mitochondrial Calcium Uniporter Channel to Limit Mitochondrial Calcium Overload During Stress. Circulation 2019, 140, 1720-1733. [CrossRef] [PubMed]

132. Sancak, Y.; Markhard, A.L.; Kitami, T.; Kovács-Bogdán, E.; Kamer, K.J.; Udeshi, N.D.; Carr, S.A.; Chaudhuri, D.; Clapham, D.E.; Li, A.A.; et al. EMRE Is an Essential Component of the Mitochondrial Calcium Uniporter Complex. Science 2013, 342, 1379-1382. [CrossRef] [PubMed]

133. Perocchi, F.; Gohil, V.M.; Girgis, H.S.; Bao, X.R.; McCombs, J.E.; Palmer, A.E.; Mootha, V.K. MICU1 encodes a mitochondrial EF hand protein required for $\mathrm{Ca}^{2+}$ uptake. Nat. Cell Biol. 2010, 467, 291-296. [CrossRef] [PubMed]

134. Mallilankaraman, K.; Doonan, P.J.; Cárdenas, C.; Chandramoorthy, H.C.; Müller, M.; Miller, R.; Hoffman, N.E.; Gandhirajan, R.K.; Molgó, J.; Birnbaum, M.J.; et al. MICU1 Is an Essential Gatekeeper for MCU-Mediated Mitochondrial $\mathrm{Ca}^{2+}$ Uptake that Regulates Cell Survival. Cell 2012, 151, 630-644. [CrossRef] [PubMed]

135. Patron, M.; Checchetto, V.; Raffaello, A.; Teardo, E.; Reane, D.V.; Mantoan, M.; Granatiero, V.; Szabò, I.; De Stefani, D.; Rizzuto, R. MICU1 and MICU2 Finely Tune the Mitochondrial $\mathrm{Ca}^{2+}$ Uniporter by Exerting Opposite Effects on MCU Activity. Mol. Cell 2014, 53, 726-737. [CrossRef] [PubMed]

136. Csordás, G.; Golenár, T.; Seifert, E.L.; Kamer, K.J.; Sancak, Y.; Perocchi, F.; Moffat, C.; Weaver, D.; Perez, S.D.L.F.; Bogorad, R.; et al. MICU1 Controls Both the Threshold and Cooperative Activation of the Mitochondrial $\mathrm{Ca}^{2+}$ Uniporter. Cell Metab. 2013, 17, 976-987. [CrossRef]

137. Plovanich, M.; Bogorad, R.L.; Sancak, Y.; Kamer, K.J.; Strittmatter, L.; Li, A.A.; Girgis, H.S.; Kuchimanchi, S.; De Groot, J.; Speciner, L.; et al. MICU2, a paralog of MICU1, resides within the mitochondrial uniporter complex to regulate calcium handling. PLoS ONE 2013, 8, e55785. [CrossRef]

138. Patron, M.; Granatiero, V.; Espino, J.; Rizzuto, R.; De Stefani, D. MICU3 is a tissue-specific enhancer of mitochondrial calcium uptake. Cell Death Differ. 2018, 26, 179-195. [CrossRef]

139. Mallilankaraman, K.; Cárdenas, C.; Doonan, P.J.; Chandramoorthy, H.C.; Irrinki, K.M.; Golenár, T.; Csordás, G.; Madireddi, P.; Yang, J.; Müller, M.; et al. MCUR1 is an essential component of mitochondrial $\mathrm{Ca}^{2+}$ uptake that regulates cellular metabolism. Nat. Cell Biol. 2012, 14, 1336-1343. [CrossRef] 
140. Hoffman, N.E.; Chandramoorthy, H.C.; Shanmughapriya, S.; Zhang, X.Q.; Vallem, S.; Doonan, P.J.; Malliankaraman, K.; Guo, S.; Rajan, S.; Elrod, J.W.; et al. SLC25A23 augments mitochondrial Ca ${ }^{2+}$ uptake, interacts with MCU, and induces oxidative stress-mediated cell death. Mol. Biol. Cell 2014, 25, 936-947. [CrossRef]

141. Palty, R.; Silverman, W.F.; Hershfinkel, M.; Caporale, T.; Sensi, S.L.; Parnis, J.; Nolte, C.; Fishman, D.; Shoshan-Barmatz, V.; Herrmann, S.; et al. NCLX is an essential component of mitochondrial $\mathrm{Na}^{+} / \mathrm{Ca}^{2+}$ exchange. Proc. Nat. Acad. Sci. USA 2010, 107, 436-441. [CrossRef] [PubMed]

142. Jiang, D.; Zhao, L.; Clapham, D.E. Genome-wide RNAi screen identifies Letm1 as a mitochondrial $\mathrm{Ca}^{2+} / \mathrm{H}^{+}$ antiporter. Science 2009, 326, 144-147. [CrossRef] [PubMed]

143. Baumgartner, H.K.; Gerasimenko, J.V.; Thorne, C.; Ferdek, P.; Pozzan, T.; Tepikin, A.V.; Petersen, O.H.; Sutton, R.; Watson, A.J.; Gerasimenko, O.V.; et al. Calcium elevation in mitochondria is the main $\mathrm{Ca}^{2+}$ requirement for mitochondrial permeability transition pore (mPTP) opening. J. Biol. Chem. 2009, 284, 20796-20803. [CrossRef] [PubMed]

144. Hengartner, M.O. The biochemistry of apoptosis. Nat. Cell Biol. 2000, 407, 770-776. [CrossRef]

145. Swerdlow, R.H.; Khan, S.M. A "mitochondrial cascade hypothesis" for sporadic Alzheimer's disease. Med. Hypotheses 2004, 63, 8-20. [CrossRef]

146. Hirai, K.; Aliev, G.; Nunomura, A.; Fujioka, H.; Russell, R.L.; Atwood, C.S.; Johnson, A.B.; Kress, Y.; Vinters, H.V.; Tabaton, M.; et al. Mitochondrial Abnormalities in Alzheimer's Disease. J. Neurosci. 2001, 21, 3017-3023. [CrossRef]

147. Rice, A.C.; Keeney, P.M.; Algarzae, N.K.; Ladd, A.C.; Thomas, R.R.; Bennett, J.P., Jr. Mitochondrial DNA Copy Numbers in Pyramidal Neurons are Decreased and Mitochondrial Biogenesis Transcriptome Signaling is Disrupted in Alzheimer's Disease Hippocampi. J. Alzheimer's Dis. 2014, 40, 319-330. [CrossRef]

148. Butterfield, D.A.; Halliwell, B. Oxidative stress, dysfunctional glucose metabolism and Alzheimer disease. Nat. Rev. Neurosci. 2019, 20, 148-160. [CrossRef]

149. Wang, J.; Markesbery, W.R.; Lovell, M.A. Increased oxidative damage in nuclear and mitochondrial DNA in mild cognitive impairment. J. Neurochem. 2006, 96, 825-832. [CrossRef]

150. Area-Gomez, E.; De Groof, A.; Bonilla, E.; Montesinos, J.; Tanji, K.; Boldogh, I.; Pon, L.; Schon, E.A. A key role for MAM in mediating mitochondrial dysfunction in Alzheimer disease. Cell Death Dis. 2018, 9, 1-10. [CrossRef]

151. Calkins, M.J.; Reddy, P.H. Amyloid beta impairs mitochondrial anterograde transport and degenerates synapses in Alzheimer's disease neurons. Biochim. Biophys. Acta (BBA) Mol. Basis Dis. 2011, 1812, 507-513. [CrossRef] [PubMed]

152. Hansson Petersen, C.A.; Alikhani, N.; Behbahani, H.; Wiehager, B.; Pavlov, P.F.; Alafuzoff, I.; Leinonen, V.; Ito, A.; Winblad, B.; Glaser, E.; et al. The amyloid beta-peptide is imported into mitochondria via the TOM import machinery and localized to mitochondrial cristae. Proc. Natl. Acad. Sci. USA 2008, 105, 13145-13150. [CrossRef] [PubMed]

153. Cieri, D.; Vicario, M.; Vallese, F.; D’Orsi, B.; Berto, P.; Grinzato, A.; Catoni, C.; De Stefani, D.; Rizzuto, R.; Brini, M.; et al. Tau localises within mitochondrial sub-compartments and its caspase cleavage affects ER-mitochondria interactions and cellular $\mathrm{Ca}^{2+}$ handling. Biochim. Biophys. Acta (BBA) Mol. Basis Dis. 2018, 1864, 3247-3256. [CrossRef] [PubMed]

154. Amadoro, G.; Corsetti, V.; Stringaro, A.; Colone, M.; D’Aguanno, S.; Meli, G.; Ciotti, M.; Sancesario, G.; Cattaneo, A.; Bussani, R.; et al. A NH2 Tau Fragment Targets Neuronal Mitochondria at AD Synapses: Possible Implications for Neurodegeneration. J. Alzheimer's Dis. 2010, 21, 445-470. [CrossRef] [PubMed]

155. Calvo-Rodríguez, M.; García-Durillo, M.; Villalobos, C.; Núñez, L. Aging Enables Ca ${ }^{2+}$ Overload and Apoptosis Induced by Amyloid-beta Oligomers in Rat Hippocampal Neurons: Neuroprotection by Non-Steroidal Anti-Inflammatory Drugs and R-Flurbiprofen in Aging Neurons. J. Alzheimer's Dis. JAD 2016, 54, 207-221. [CrossRef]

156. Sanz-Blasco, S.; Valero, R.A.; Rodriguez-Crespo, I.; Villalobos, C.; Nunez, L. Mitochondrial Ca ${ }^{2+}$ overload underlies Abeta oligomers neurotoxicity providing an unexpected mechanism of neuroprotection by NSAIDs. PLoS ONE 2008, 3, e2718. [CrossRef]

157. Calvo-Rodriguez, M.; Hou, S.S.; Snyder, A.C.; Kharitonova, E.K.; Russ, A.N.; Das, S.; Fan, Z.; Muzikansky, A.; Garcia-Alloza, M.; Serrano-Pozo, A.; et al. Increased mitochondrial calcium levels associated with neuronal death in a mouse model of Alzheimer's disease. Nat. Commun. 2020, 11, 1-17. [CrossRef] 
158. Yan, Y.; Gong, K.; Ma, T.; Zhang, L.; Zhao, N.; Zhang, X.; Tang, P.; Gong, Y. Protective effect of edaravone against Alzheimer's disease-relevant insults in neuroblastoma N2a cells. Neurosci. Lett. 2012, 531, 160-165. [CrossRef]

159. Moreira, P.I.; Santos, M.S.; Moreno, A.; Oliveira, C. Amyloid $\beta$-Peptide Promotes Permeability Transition Pore in Brain Mitochondria. Biosci. Rep. 2001, 21, 789-800. [CrossRef]

160. Du, H.; Guo, L.; Fang, F.; Chen, D.; A Sosunov, A.; McKhann, G.M.; Yan, Y.; Wang, C.; Zhang, H.; Molkentin, J.D.; et al. Cyclophilin D deficiency attenuates mitochondrial and neuronal perturbation and ameliorates learning and memory in Alzheimer's disease. Nat. Med. 2008, 14, 1097-1105. [CrossRef]

161. Jadiya, P.; Kolmetzky, D.W.; Tomar, D.; Di Meco, A.; Lombardi, A.A.; Lambert, J.P.; Luongo, T.S.; Ludtmann, M.H.; Praticò, D.; Elrod, J.W. Impaired mitochondrial calcium efflux contributes to disease progression in models of Alzheimer's disease. Nat. Commun. 2019, 10, 1-14. [CrossRef] [PubMed]

162. Kern, S.; Skoog, I.; Östling, S.; Kern, J.; Börjesson-Hanson, A. Does low-dose acetylsalicylic acid prevent cognitive decline in women with high cardiovascular risk? A 5-year follow-up of a non-demented population-based cohort of Swedish elderly women. BMJ Open 2012, 2, e001288. [CrossRef] [PubMed]

163. Zhang, C.; Wang, Y.; Wang, D.; Zhang, J.; Zhang, F. NSAID Exposure and Risk of Alzheimer's Disease: An Updated Meta-Analysis From Cohort Studies. Front. Aging Neurosci. 2018, 10, 83. [CrossRef] [PubMed]

164. Breitner, J.; Meyer, P.-F. Author response: INTREPAD: A randomized trial of naproxen to slow progress of presymptomatic Alzheimer disease. Neurology 2020, 94, 594. [CrossRef] [PubMed]

165. Sanz-Blasco, S.; Calvo-Rodriguez, M.; Caballero, E.; Garcia-Durillo, M.; Nunez, L.; Villalobos, C. Is it All Said for NSAIDs in Alzheimer's Disease? Role of Mitochondrial Calcium Uptake. Curr. Alzheimer Res. 2018, 15, 504-510. [CrossRef] [PubMed]

166. Gutknecht, J. Salicylates and proton transport through lipid bilayer membranes: A model for salicylate-induced uncoupling and swelling in mitochondria. J. Membr. Biol. 1990, 115, 253-260. [CrossRef]

167. Núñez, L.; Valero, R.A.; Senovilla, L.; Sanz-Blasco, S.; García-Sancho, J.; Villalobos, C. Cell proliferation depends on mitochondrial $\mathrm{Ca}^{2+}$ uptake: Inhibition by salicylate. J. Physiol. 2006, 571, 57-73. [CrossRef]

168. Calvo-Rodríguez, M.; Sanz-Blasco, S.; Caballero, E.; Villalobos, C.; Núñez, L. Susceptibility to excitotoxicity in aged hippocampal cultures and neuroprotection by non-steroidal anti-inflammatory drugs: Role of mitochondrial calcium. J. Neurochem. 2015, 132, 403-417. [CrossRef]

169. Angelova, P.R.; Vinogradova, D.; Neganova, M.E.; Serkova, T.P.; Sokolov, V.V.; Bachurin, S.O.; Shevtsova, E.F.; Abramov, A.Y. Pharmacological Sequestration of Mitochondrial Calcium Uptake Protects Neurons Against Glutamate Excitotoxicity. Mol. Neurobiol. 2019, 56, 2244-2255. [CrossRef]

170. Dubey, M.; Chaudhury, P.; Kabiru, H.; Shea, T.B. Tau inhibits anterograde axonal transport and perturbs stability in growing axonal neurites in part by displacing kinesin cargo: Neurofilaments attenuate tau-mediated neurite instability. Cell Motil. Cytoskelet. 2008, 65, 89-99. [CrossRef]

171. DuBoff, B.; Götz, J.; Feany, M.B. Tau Promotes Neurodegeneration via DRP1 Mislocalization In Vivo. Neuron 2012, 75, 618-632. [CrossRef] [PubMed]

172. Quintanilla, R.A.; Matthews-Roberson, T.A.; Dolan, P.J.; Johnson, G.V. Caspase-cleaved Tau Expression Induces Mitochondrial Dysfunction in Immortalized Cortical Neurons. J. Biol. Chem. 2009, 284, 18754-18766. [CrossRef] [PubMed]

173. Britti, E.; Ros, J.; Esteras, N.; Abramov, A.Y. Tau inhibits mitochondrial calcium efflux and makes neurons vulnerable to calcium-induced cell death. Cell Calcium 2020, 86, 102150. [CrossRef] [PubMed]

174. Manczak, M.; Reddy, P.H. Abnormal interaction between the mitochondrial fission protein Drp1 and hyperphosphorylated tau in Alzheimer's disease neurons: Implications for mitochondrial dysfunction and neuronal damage. Hum. Mol. Genet. 2012, 21, 2538-2547. [CrossRef]

175. García-Pérez, C.; Hajnóczky, G.; Csordás, G. Physical Coupling Supports the Local Ca ${ }^{2+}$ Transfer between Sarcoplasmic Reticulum Subdomains and the Mitochondria in Heart Muscle. J. Biol. Chem. 2008, 283, 32771-32780. [CrossRef]

176. Hayashi, T.; Su, T.-P. Sigma-1 Receptor Chaperones at the ER- Mitochondrion Interface Regulate Ca ${ }^{2+}$ Signaling and Cell Survival. Cell 2007, 131, 596-610. [CrossRef]

177. Csordas, G.; Varnai, P.; Golenar, T.; Roy, S.; Purkins, G.; Schneider, T.G.; Balla, T.; Hajnoczky, G. Imaging interorganelle contacts and local calcium dynamics at the ER-mitochondrial interface. Mol. Cell 2010, 39, 121-132. [CrossRef] 
178. Area-Gomez, E.; Schon, E.A. On the Pathogenesis of Alzheimer's Disease: The MAM Hypothesis. FASEB J. 2017, 31, 864-867. [CrossRef]

179. Hedskog, L.; Pinho, C.M.; Filadi, R.; Rönnbäck, A.; Hertwig, L.; Wiehager, B.; Larssen, P.; Gellhaar, S.; Sandebring, A.; Westerlund, M.; et al. Modulation of the endoplasmic reticulum-mitochondria interface in Alzheimer's disease and related models. Proc. Nat. Acad. Sci. USA 2013, 110, 7916-7921. [CrossRef]

180. Perreault, S.; Bousquet, O.; Lauzon, M.; Paiement, J.; Leclerc, N. Increased Association Between Rough Endoplasmic Reticulum Membranes and Mitochondria in Transgenic Mice That Express P301L Tau. J. Neuropathol. Exp. Neurol. 2009, 68, 503-514. [CrossRef]

181. Area-Gomez, E.; Castillo, M.D.C.L.; Tambini, M.D.; Guardia-Laguarta, C.; De Groof, A.J.C.; Madra, M.; Ikenouchi, J.; Umeda, M.; Bird, T.D.; Sturley, S.L.; et al. Upregulated function of mitochondria-associated ER membranes in Alzheimer disease. EMBO J. 2012, 31, 4106-4123. [CrossRef] [PubMed]

182. Ferreiro, E.; Oliveira, C.R.; Pereira, C.F. The release of calcium from the endoplasmic reticulum induced by amyloid-beta and prion peptides activates the mitochondrial apoptotic pathway. Neurobiol. Dis. 2008, 30, 331-342. [CrossRef] [PubMed]

183. Zampese, E.; Fasolato, C.; Kipanyula, M.J.; Bortolozzi, M.; Pozzan, T.; Pizzo, P. Presenilin 2 modulates endoplasmic reticulum (ER)-mitochondria interactions and $\mathrm{Ca}^{2+}$ cross-talk. Proc. Nat. Acad. Sci. USA 2011, 108, 2777-2782. [CrossRef] [PubMed]

184. Zhu, X.; Smith, M.A.; Perry, G.H.; Aliev, G. Mitochondrial failures in Alzheimer's disease. Am. J. Alzheimer's Dis. Other Dement. 2004, 19, 345-352. [CrossRef] [PubMed]

185. Cenini, G.; Voos, W. Mitochondria as Potential Targets in Alzheimer Disease Therapy: An Update. Front. Pharmacol. 2019, 10, 902. [CrossRef] [PubMed]

186. Kelso, G.F.; Porteous, C.M.; Coulter, C.V.; Hughes, G.; Porteous, W.K.; Ledgerwood, E.C.; Smith, R.A.J.; Murphy, M.P. Selective targeting of a redox-active ubiquinone to mitochondria within cells: Antioxidant and antiapoptotic properties. J. Biol. Chem. 2001, 276, 4588-4596. [CrossRef]

187. Ortiz, J.M.P.; Swerdlow, R.H. Mitochondrial dysfunction in Alzheimer's disease: Role in pathogenesis and novel therapeutic opportunities. Br. J. Pharmacol. 2019, 176, 3489-3507. [CrossRef]

188. Szeto, H.H. Cell-permeable, mitochondrial-targeted, peptide antioxidants. AAPS J. 2006, 8, E277-E283. [CrossRef]

189. Birk, A.V.; Chao, W.M.; Bracken, C.; Warren, J.D.; Szeto, H.H. Targeting mitochondrial cardiolipin and the cytochromec/cardiolipin complex to promote electron transport and optimize mitochondrial ATP synthesis. Br. J. Pharmacol. 2014, 171, 2017-2028. [CrossRef]

190. Reddy, P.H.; Manczak, M.; Kandimalla, R. Mitochondria-targeted small molecule SS31: A potential candidate for the treatment of Alzheimer's disease. Hum. Mol. Genet. 2017, 26, 1597. [CrossRef]

191. Reddy, P.H.; Manczak, M.; Yin, X.; Reddy, A.P. Synergistic Protective Effects of Mitochondrial Division Inhibitor 1 and Mitochondria-Targeted Small Peptide SS31 in Alzheimer's Disease. J. Alzheimer's Dis. 2018, 62, 1549-1565. [CrossRef] [PubMed]

192. Wilkins, H.M.; Morris, J.K. New Therapeutics to Modulate Mitochondrial Function in Neurodegenerative Disorders. Curr. Pharm. Des. 2017, 23, 731-752. [CrossRef] [PubMed]

193. Lloyd-Evans, E.; Platt, F.M. Lysosomal $\mathrm{Ca}^{2+}$ homeostasis: Role in pathogenesis of lysosomal storage diseases. Cell Calcium 2011, 50, 200-205. [CrossRef] [PubMed]

194. Tian, X.; Gala, U.; Zhang, Y.; Shang, W.; Jaiswal, S.N.; Di Ronza, A.; Jaiswal, M.; Yamamoto, S.; Sandoval, H.; DuRaine, L.; et al. A voltage-gated calcium channel regulates lysosomal fusion with endosomes and autophagosomes and is required for neuronal homeostasis. PLoS Biol. 2015, 13, e1002103. [CrossRef] [PubMed]

195. Patel, S.; Docampo, R. Acidic calcium stores open for business: Expanding the potential for intracellular $\mathrm{Ca}^{2+}$ signaling. Trends Cell Biol. 2010, 20, 277-286. [CrossRef] [PubMed]

196. Garrity, A.G.; Wang, W.; Collier, C.M.; A Levey, S.; Gao, Q.; Xu, H. The endoplasmic reticulum, not the pH gradient, drives calcium refilling of lysosomes. eLife 2016, 5, e15887. [CrossRef] [PubMed]

197. Mindell, J.A. Lysosomal Acidification Mechanisms. Annu. Rev. Physiol. 2012, 74, 69-86. [CrossRef]

198. Bach, G.; Chen, C.-S.; E Pagano, R. Elevated lysosomal pH in Mucolipidosis type IV cells. Clin. Chim. Acta 1999, 280, 173-179. [CrossRef] 
199. Soyombo, A.A.; Tjon-Kon-Sang, S.; Rbaibi, Y.; Bashllari, E.; Bisceglia, J.; Muallem, S.; Kiselyov, K. TRP-ML1 Regulates Lysosomal pH and Acidic Lysosomal Lipid Hydrolytic Activity. J. Biol. Chem. 2006, 281, 7294-7301. [CrossRef]

200. Medina, D.L.; Di Paola, S.; Peluso, I.; Armani, A.; De Stefani, D.; Venditti, R.; Montefusco, S.; Scotto-Rosato, A.; Prezioso, C.; Forrester, A.; et al. Lysosomal calcium signalling regulates autophagy through calcineurin and TFEB. Nat. Cell Biol. 2015, 17, 288-299. [CrossRef]

201. Lee, J.-H.; McBrayer, M.K.; Wolfe, D.M.; Haslett, L.J.; Kumar, A.; Sato, Y.; Lie, P.P.Y.; Mohan, P.S.; Coffey, E.E.; Kompella, U.B.; et al. Presenilin 1 Maintains Lysosomal $\mathrm{Ca}^{2+}$ Homeostasis via TRPML1 by Regulating vATPase-Mediated Lysosome Acidification. Cell Rep. 2015, 12, 1430-1444. [CrossRef] [PubMed]

202. Neely, K.M.; Green, K.N.; LaFerla, F.M. Presenilin is necessary for efficient proteolysis through the autophagy-lysosome system in a gamma-secretase-independent manner. J. Neurosci. 2011, 31, 2781-2791. [CrossRef] [PubMed]

203. Greotti, E.; Capitanio, P.; Wong, A.; Pozzan, T.; Pizzo, P.; Pendin, D. Familial Alzheimer's disease-linked presenilin mutants and intracellular $\mathrm{Ca}^{2+}$ handling: A single-organelle, FRET-based analysis. Cell Calcium 2019, 79, 44-56. [CrossRef] [PubMed]

204. Glick, D.; Barth, S.; MacLeod, K.F. Autophagy: Cellular and molecular mechanisms. J. Pathol. 2010, $221,3-12$. [CrossRef]

205. Nixon, R.A.; Wegiel, J.; Kumar, A.; Yu, W.H.; Peterhoff, C.; Cataldo, A.; Cuervo, A.M. Extensive Involvement of Autophagy in Alzheimer Disease: An Immuno-Electron Microscopy Study. J. Neuropathol. Exp. Neurol. 2005, 64, 113-122. [CrossRef]

206. Pickford, F.; Masliah, E.; Britschgi, M.; Lucin, K.; Narasimhan, R.; Jaeger, P.A.; Small, S.; Spencer, B.; Rockenstein, E.; Levine, B.; et al. The autophagy-related protein beclin 1 shows reduced expression in early Alzheimer disease and regulates amyloid $\beta$ accumulation in mice. J. Clin. Investig. 2008, 118, 2190-2199. [CrossRef]

207. Wolfe, D.M.; Lee, J.-H.; Kumar, A.; Lee, S.; Orenstein, S.J.; Nixon, R.A. Autophagy failure in Alzheimer's disease and the role of defective lysosomal acidification. Eur. J. Neurosci. 2013, 37, 1949-1961. [CrossRef]

208. Medeiros, R.; LaFerla, F.M. Astrocytes: Conductors of the Alzheimer disease neuroinflammatory symphony. Exp. Neurol. 2013, 239, 133-138. [CrossRef]

209. Verkhratsky, A.; Parpura, V. Recent advances in (patho)physiology of astroglia. Acta Pharmacol. Sin. 2010, 31, 1044-1054. [CrossRef]

210. Abbott, N.J.; Rönnbäck, L.; Hansson, E. Astrocyte-endothelial interactions at the blood-brain barrier. Nat. Rev. Neurosci. 2006, 7, 41-53. [CrossRef]

211. Guerra-Gomes, S.; Sousa, N.; Pinto, L.; Oliveira, J.F. Functional Roles of Astrocyte Calcium Elevations: From Synapses to Behavior. Front. Cell. Neurosci. 2018, 11, 427. [CrossRef] [PubMed]

212. Verkhratsky, A.; Nedergaard, M. Physiology of Astroglia. Physiol. Rev. 2018, 98, 239-389. [CrossRef] [PubMed]

213. Perez-Nievas, B.G.; Serrano-Pozo, A. Deciphering the Astrocyte Reaction in Alzheimer's Disease. Front. Aging Neurosci. 2018, 10, 114. [CrossRef] [PubMed]

214. Lim, D.; Iyer, A.; Ronco, V.; A Grolla, A.; Canonico, P.L.; Aronica, E.; Genazzani, A.A. Amyloid beta deregulates astroglial mGluR5-mediated calcium signaling via calcineurin and Nf-kB. Glia 2013, 61, 1134-1145. [CrossRef]

215. Grolla, A.A.; Sim, J.A.; Lim, D.; Rodriguez, J.J.; Genazzani, A.A.; Verkhratsky, A. Amyloid-beta and Alzheimer's disease type pathology differentially affects the calcium signalling toolkit in astrocytes from different brain regions. Cell Death Dis. 2013, 4, e623. [CrossRef]

216. Alberdi, E.; Wyssenbach, A.; Alberdi, M.; Sanchez-Gomez, M.V.; Cavaliere, F.; Rodriguez, J.J.; Verkhratsky, A.; Matute, C. $\mathrm{Ca}^{2+}$-dependent endoplasmic reticulum stress correlates with astrogliosis in oligomeric amyloid beta-treated astrocytes and in a model of Alzheimer's disease. Aging Cell 2013, 12, 292-302. [CrossRef]

217. Abramov, A.Y.; Canevari, L.; Duchen, M.R. Changes in Intracellular Calcium and Glutathione in Astrocytes as the Primary Mechanism of Amyloid Neurotoxicity. J. Neurosci. 2003, 23, 5088-5095. [CrossRef]

218. Toivari, E.; Manninen, T.; Nahata, A.K.; Jalonen, T.O.; Linne, M.-L. Effects of Transmitters and Amyloid-Beta Peptide on Calcium Signals in Rat Cortical Astrocytes: Fura-2AM Measurements and Stochastic Model Simulations. PLoS ONE 2011, 6, e17914. [CrossRef] 
219. Larramona-Arcas, R.; González-Arias, C.; Perea, G.; Gutiérrez, A.; Vitorica, J.; García-Barrera, T.; Gómez-Ariza, J.L.; Pascua-Maestro, R.; Ganfornina, M.D.; Kara, E.; et al. Sex-dependent calcium hyperactivity due to lysosomal-related dysfunction in astrocytes from APOE4 versus APOE3 gene targeted replacement mice. Mol. Neurodegener. 2020, 15, 1-23. [CrossRef]

220. Hirase, H.; Qian, L.; Barthó, P.; Buzsáki, G. Calcium Dynamics of Cortical Astrocytic Networks In Vivo. PLoS Biol. 2004, 2, e96. [CrossRef]

221. Torres, A.; Wang, F.; Xu, Q.; Fujita, T.; Dobrowolski, R.; Willecke, K.; Takano, T.; Nedergaard, M. Extracellular $\mathrm{Ca}^{2+}$ Acts as a Mediator of Communication from Neurons to Glia. Sci. Signal. 2012, 5, ra8. [CrossRef] [PubMed]

222. Paolicelli, R.C.; Bolasco, G.; Pagani, F.; Maggi, L.; Scianni, M.; Panzanelli, P.; Giustetto, M.; Ferreira, T.A.; Guiducci, E.; Dumas, L.; et al. Synaptic Pruning by Microglia Is Necessary for Normal Brain Development. Science 2011, 333, 1456-1458. [CrossRef] [PubMed]

223. Von Bernhardi, R.; Tichauer, J.E.; Eugenín, J. Aging-dependent changes of microglial cells and their relevance for neurodegenerative disorders. J. Neurochem. 2010, 112, 1099-1114. [CrossRef] [PubMed]

224. Hoffmann, A.; Kann, O.; Ohlemeyer, C.; Hanisch, U.-K.; Kettenmann, H. Elevation of Basal Intracellular Calcium as a Central Element in the Activation of Brain Macrophages (Microglia): Suppression of Receptor-Evoked Calcium Signaling and Control of Release Function. J. Neurosci. 2003, 23, 4410-4419. [CrossRef] [PubMed]

225. Franciosi, S.; Choi, H.B.; Kim, S.U.; McLarnon, J.G. Interferon-? acutely induces calcium influx in human microglia. J. Neurosci. Res. 2002, 69, 607-613. [CrossRef]

226. Goghari, V.; Franciosi, S.; Kim, S.U.; Lee, Y.B.; McLarnon, J.G. Acute application of interleukin-1beta induces $\mathrm{Ca}^{2+}$ responses in human microglia. Neurosci. Lett. 2000, 281, 83-86. [CrossRef]

227. McLarnon, J.G.; Franciosi, S.; Wang, X.; Bae, J.; Choi, H.; Kim, S. Acute actions of tumor necrosis factor- $\alpha$ on intracellular $\mathrm{Ca}^{2+}$ and $\mathrm{K}^{+}$currents in human microglia. Neuroscience 2001, 104, 1175-1184. [CrossRef]

228. Turovskaya, M.V.; Turovsky, E.A.; Zinchenko, V.P.; Levin, S.G.; Godukhin, O.V. Interleukin-10 modulates $\left[\mathrm{Ca}^{2+}\right]$ i response induced by repeated NMDA receptor activation with brief hypoxia through inhibition of InsP3-sensitive internal stores in hippocampal neurons. Neurosci. Lett. 2012, 516, 151-155. [CrossRef]

229. Itagaki, S.; McGeer, P.; Akiyama, H.; Zhu, S.; Selkoe, D. Relationship of microglia and astrocytes to amyloid deposits of Alzheimer disease. J. Neuroimmunol. 1989, 24, 173-182. [CrossRef]

230. Meyer-Luehmann, M.; Spires-Jones, T.L.; Prada, C.; Garcia-Alloza, M.; de Calignon, A.; Rozkalne, A.; Koenigsknecht-Talboo, J.; Holtzman, D.M.; Bacskai, B.J.; Hyman, B.T. Rapid appearance and local toxicity of amyloid-beta plaques in a mouse model of Alzheimer's disease. Nature 2008, 451, 720-724. [CrossRef]

231. Perez-Nievas, B.G.; Stein, T.D.; Tai, H.-C.; Dols-Icardo, O.; Scotton, T.C.; Barroeta-Espar, I.; Fernandez-Carballo, L.; De Munain, E.L.; Perez, J.; Marquie, M.; et al. Dissecting phenotypic traits linked to human resilience to Alzheimer's pathology. Brain 2013, 136, 2510-2526. [CrossRef] [PubMed]

232. Bezzi, P.; Domercq, M.; Brambilla, L.; Galli, R.; Schols, D.; De Clercq, E.; Vescovi, A.; Bagetta, G.; Kollias, G.; Meldolesi, J.; et al. CXCR4-activated astrocyte glutamate release via TNFalpha: Amplification by microglia triggers neurotoxicity. Nat. Neurosci. 2001, 4, 702-710. [CrossRef] [PubMed]

233. Agulhon, C.; Sun, M.-Y.; Murphy, T.; Myers, T.; Lauderdale, K.; Fiacco, T.A. Calcium Signaling and Gliotransmission in Normal vs. Reactive Astrocytes. Front. Pharmacol. 2012, 3, 139. [CrossRef] [PubMed]

234. Brawek, B.; Garaschuk, O. Network-wide dysregulation of calcium homeostasis in Alzheimer's disease. Cell Tissue Res. 2014, 357, 427-438. [CrossRef] [PubMed]

235. Silei, V.; Fabrizi, C.; Venturini, G.; Salmona, M.; Bugiani, O.; Tagliavini, F.; Lauro, G.M. Activation of microglial cells by PrP and beta-amyloid fragments raises intracellular calcium through L-type voltage sensitive calcium channels. Brain Res. 1999, 818, 168-170. [CrossRef]

236. McLarnon, J.G.; Choi, H.B.; Lue, L.-F.; Walker, D.G.; Kim, S.U. Perturbations in calcium-mediated signal transduction in microglia from Alzheimer's disease patients. J. Neurosci. Res. 2005, 81, 426-435. [CrossRef] [PubMed]

237. Eichhoff, G.; Brawek, B.; Garaschuk, O. Microglial calcium signal acts as a rapid sensor of single neuron damage in vivo. Biochim. Biophys. Acta (BBA) Bioenerg. 2011, 1813, 1014-1024. [CrossRef]

238. Heo, D.K.; Lim, H.M.; Nam, J.H.; Lee, M.G.; Kim, J.Y. Regulation of phagocytosis and cytokine secretion by store-operated calcium entry in primary isolated murine microglia. Cell. Signal. 2015, 27, 177-186. [CrossRef] 
239. Michaelis, M.; Nieswandt, B.; Stegner, D.; Eilers, J.; Kraft, R. STIM1, STIM2, and Orai1 regulate store-operated calcium entry and purinergic activation of microglia. Glia 2015, 63, 652-663. [CrossRef]

240. Klegeris, A.; Choi, H.B.; McLarnon, J.G.; McGeer, P.L. Functional ryanodine receptors are expressed by human microglia and THP-1 cells: Their possible involvement in modulation of neurotoxicity. J. Neurosci. Res. 2007, 85, 2207-2215. [CrossRef]

241. Lim, H.M.; Woon, H.; Han, J.W.; Baba, Y.; Kurosaki, T.; Lee, M.G.; Kim, J.Y. UDP-Induced Phagocytosis and ATP-Stimulated Chemotactic Migration Are Impaired in STIM1(-/-) Microglia In Vitro and In Vivo. Mediat. Inflamm. 2017, 2017, 8158514. [CrossRef] [PubMed]

242. Burnstock, G. Purinergic Signalling: Therapeutic Developments. Front. Pharmacol. 2017, 8, 661. [CrossRef] [PubMed]

243. Harada, H.; Chan, C.M.; Loesch, A.; Unwin, R.; Burnstock, G. Induction of proliferation and apoptotic cell death via P2Y and P2X receptors, respectively, in rat glomerular mesangial cells. Kidney Int. 2000, 57, 949-958. [CrossRef] [PubMed]

244. McLarnon, J.G.; Ryu, J.K.; Walker, D.G.; Choi, H.B. Upregulated expression of purinergic P2X(7) receptor in Alzheimer disease and amyloid-beta peptide-treated microglia and in peptide-injected rat hippocampus. Exp. Neurol. 2006, 65, 1090-1097.

245. Parvathenani, L.K.; Tertyshnikova, S.; Greco, C.R.; Roberts, S.B.; Robertson, B.; Posmantur, R. P2 $\times 7$ mediates superoxide production in primary microglia and is up-regulated in a transgenic mouse model of Alzheimer's disease. J. Biol. Chem. 2003, 278, 13309-13317. [CrossRef]

246. Sanz, J.M.; Chiozzi, P.; Ferrari, D.; Colaianna, M.; Idzko, M.; Falzoni, S.; Fellin, R.; Trabace, L.; Di Virgilio, F. Activation of microglia by amyloid \{beta\} requires $\mathrm{P} 2 \times 7$ receptor expression. J. Immunol. Res. 2009, 182, 4378-4385.

247. Illes, P.; Rubini, P.; Huang, L.; Tang, Y. The P $2 \times 7$ receptor: A new therapeutic target in Alzheimer's disease. Expert Opin. 2019, 23, 165-176.

248. Jana, M.K.; Cappai, R.; Ciccotosto, G.D. Oligomeric Amyloid-beta Toxicity Can Be Inhibited by Blocking Its Cellular Binding in Cortical Neuronal Cultures with Addition of the Triphenylmethane Dye Brilliant Blue, G. ACS Chem. Biol. 2016, 7, 1141-1147.

249. Diaz-Hernandez, J.I.; Gomez-Villafuertes, R.; Leon-Otegui, M.; Hontecillas-Prieto, L.; Del Puerto, A.; Trejo, J.L.; Lucas, J.J.; Garrido, J.J.; Gualix, J.; Miras-Portugal, M.T.; et al. In vivo P2 $\times 7$ inhibition reduces amyloid plaques in Alzheimer's disease through GSK3beta and secretases. Neurobiol. Aging 2012, 33, 1816-1828. [CrossRef]

250. Martin, E.; Amar, M.; Dalle, C.; Youssef, I.; Boucher, C.; Le Duigou, C.; Bruckner, M.; Prigent, A.; Sazdovitch, V.; Halle, A.; et al. New role of P2 $\times 7$ receptor in an Alzheimer's disease mouse model. Mol. Psychiatry 2019, 24, 108-125. [CrossRef]

251. Lee, G.-S.; Subramanian, N.; Kim, A.I.; Aksentijevich, I.; Goldbach-Mansky, R.; Sacks, D.B.; Germain, R.N.; Kastner, D.L.; Chae, J.J. The calcium-sensing receptor regulates the NLRP3 inflammasome through $\mathrm{Ca}^{2+}$ and cAMP. Nat. Cell Biol. 2012, 492, 123-127. [CrossRef] [PubMed]

252. Murakami, T.; Ockinger, J.; Yu, J.; Byles, V.; McColl, A.; Hofer, A.M.; Horng, T. Critical role for calcium mobilization in activation of the NLRP3 inflammasome. Proc. Nat. Acad. Sci. USA 2012, 109, 11282-11287. [CrossRef] [PubMed]

253. Halle, A.; Hornung, V.; Petzold, G.C.; Stewart, C.R.; Monks, B.G.; Reinheckel, T.; Fitzgerald, K.A.; Latz, E.; Moore, K.J.; Golenbock, D.T. The NALP3 inflammasome is involved in the innate immune response to amyloid-beta. Nat. Immunol. 2008, 9, 857-865. [CrossRef] [PubMed]

254. Heneka, M.T.; Kummer, M.P.; Stutz, A.; Delekate, A.; Schwartz, S.; Vieira-Saecker, A.; Griep, A.; Axt, D.; Remus, A.; Tzeng, T.-C.; et al. NLRP3 is activated in Alzheimer's disease and contributes to pathology in APP/PS1 mice. Nat. Cell Biol. 2013, 493, 674-678. [CrossRef]

255. Jonsson, T.; Stefansson, H.; Steinberg, S.; Jonsdottir, I.; Jonsson, P.V.; Snaedal, J.; Bjornsson, S.; Huttenlocher-Moser, J.; Levey, A.I.; Lah, J.J.; et al. Variant of TREM2 Associated with the Risk of Alzheimer's Disease. N. Engl. J. Med. 2013, 368, 107-116. [CrossRef]

256. Jiang, T.; Tan, L.; Zhu, X.-C.; Zhang, Q.-Q.; Cao, L.; Tan, M.-S.; Gu, L.-Z.; Wang, H.-F.; Ding, Z.-Z.; Zhang, Y.-D.; et al. Upregulation of TREM2 Ameliorates Neuropathology and Rescues Spatial Cognitive Impairment in a Transgenic Mouse Model of Alzheimer's Disease. Neuropsychopharmacology 2014, 39, 2949-2962. [CrossRef] [PubMed] 
257. Bouchon, A.; Hernández-Munain, C.; Cella, M.; Colonna, M. A Dap12-Mediated Pathway Regulates Expression of Cc Chemokine Receptor 7 and Maturation of Human Dendritic Cells. J. Exp. Med. 2001, 194, 1111-1122. [CrossRef] [PubMed]

258. Miyanohara, A.; Kamizato, K.; Juhas, S.; Juhasova, J.; Navarro, M.; Marsala, S.; Lukacova, N.; Hruska-Plochan, M.; Curtis, E.; Gabel, B.; et al. Potent spinal parenchymal AAV9-mediated gene delivery by subpial injection in adult rats and pigs. Mol. Ther. Methods Clin. Dev. 2016, 3, 16046. [CrossRef]

259. Challis, R.C.; Kumar, S.R.; Chan, K.Y.; Challis, C.; Beadle, K.; Jang, M.J.; Kim, H.M.; Rajendran, P.S.; Tompkins, J.D.; Shivkumar, K.; et al. Systemic AAV vectors for widespread and targeted gene delivery in rodents. Nat. Protoc. 2019, 14, 379-414. [CrossRef] [PubMed]

260. Alves, S.; Fol, R.; Cartier, N. Gene Therapy Strategies for Alzheimer's Disease: An Overview. Hum. Gene Ther. 2016, 27, 100-107. [CrossRef]

261. Zhao, L.; Gottesdiener, A.J.; Parmar, M.; Li, M.; Kaminsky, S.M.; Chiuchiolo, M.J.; Sondhi, D.; Sullivan, P.M.; Holtzman, D.M.; Crystal, R.G.; et al. Intracerebral adeno-associated virus gene delivery of apolipoprotein E2 markedly reduces brain amyloid pathology in Alzheimer's disease mouse models. Neurobiol. Aging 2016, 44, 159-172. [CrossRef] [PubMed]

262. Rosenberg, J.B.; Kaplitt, M.G.; De, B.P.; Chen, A.; Flagiello, T.; Salami, C.; Pey, E.; Zhao, L.; Ricart Arbona, R.J.; Monette, S.; et al. AAVrh.10-Mediated APOE2 Central Nervous System Gene Therapy for APOE4-Associated Alzheimer's Disease. Hum. Gen. Ther. Clin. Dev. 2018, 29, 24-47. [CrossRef] [PubMed]

Publisher's Note: MDPI stays neutral with regard to jurisdictional claims in published maps and institutional affiliations. 